\title{
A Review of the Varied Uses of Macroalgae as Dietary Supplements in Selected Poultry with Special Reference to Laying Hen and Broiler Chickens
}

\author{
Garima Kulshreshtha ${ }^{1, *}$, Maxwell T. Hincke ${ }^{1,2}$, Balakrishnan Prithiviraj ${ }^{3}$ and Alan Critchley ${ }^{4}$ (I) \\ 1 Department of Cellular and Molecular Medicine, Faculty of Medicine, University of Ottawa, Ottawa, \\ ON K1H 8M5, Canada; mhincke@uottawa.ca \\ 2 Department of Innovation in Medical Education, Faculty of Medicine, University of Ottawa, Ottawa, \\ ON K1H 8M5, Canada \\ 3 Department of Plant, Food, and Environmental Sciences, Agricultural Campus, Dalhousie University, \\ PO Box 550, Truro, NS B2N 5E3, Canada; bprithiviraj@dal.ca \\ 4 Verschuren Centre for Sustainability in Energy and Environment, Cape Breton University, Sydney, \\ Cape Breton, NS B1P 6L2, Canada; alan.critchley2016@gmail.com \\ * Correspondence: gkulshre@uottawa.ca
}

Received: 27 June 2020; Accepted: 15 July 2020; Published: 19 July 2020

\begin{abstract}
Seaweeds comprise ca. 12,000 species. Global annual harvest is ca. 30.13 million metric tonnes, (valued ca. \$11.7 billion USD in 2016) for various commercial applications. The growing scope of seaweed-based applications in food, agricultural fertilizers, animal feed additives, pharmaceuticals, cosmetics and personal care is expected to boost market demand. Agriculture and animal feed applications held the second largest seaweed market share in 2017, and the combined market is anticipated to reach much higher values by 2024 due to the impacts of current research and development targeting enhanced animal health and productivity. In general, seaweeds have been utilized in animal feed as a rich source of carbohydrates, protein, minerals, vitamins and dietary fibers with relatively well-balanced amino acid profiles and a unique blend of bioactive compounds. Worldwide, the animal nutrition market is largely driven by rising demand for poultry feeds, which represents ca. $47 \%$ of the total consumption for all animal nutrition. This review provides an overview of the utilization of specific seaweeds as sustainable feed sources for poultry production, including a detailed survey of seaweed-supplemented diets on growth, performance, gastrointestinal flora, disease, immunity and overall health of laying/broiler hens. Anti-microbial effects of seaweeds are also discussed.
\end{abstract}

Keywords: seaweed-supplemented feed; poultry; prebiotics; anti-microbial; gastrointestinal flora; immunity; animal nutrition market

\section{Introduction}

Algae comprise around 25,000-50,000 species, with a diversity of size, forms, pigments and functional compounds; ca. 12,000 of these are designated as macroalgae or seaweeds [1]. The global annual harvest of macroalgae is almost 36 million metric tonnes, with a market size of approximately $\$ 6$ billion USD for various commercial applications. Global seaweed production is mainly carried out in Asian countries, which accounts for over 99\% of global production [2]. Seaweeds can have high crop productivities per unit area as they do not require land and fresh water for growth, with lucrative scope for commercialization [3]. Seaweeds are a source of unique bioactive metabolites, which are not synthesized by terrestrial plants [4]. Bioactive molecules such as carbohydrates, proteins, minerals, polyphenols, pigments (chlorophylls, fucoxanthins, phycobilins), mycosporine-like amino 
acids (MAAs) and polyunsaturated fatty acids (PUFAs), including omega-3 fatty acids, have been attributed to various biological functionalities, such as anti-microbial, anti-viral, anti-inflammatory, immunomodulatory, prebiotic and cholesterol lowering effects [5]. Globally, seaweed cultivation has been growing rapidly, and it is currently produced in over 50 countries. According to the Food and Agriculture Organization (FAO), approximately 30.13 million tonnes of seaweeds were harvested in 2016 for various applications including direct consumption, food production, hydrocolloids, fertilizers and animal feed [6]. While seaweed bioactives are an appealing source for commercialization due to their various high value applications, the utilization of this resource has not been completely optimized.

Seaweeds have been utilized in animal feed as a rich source of carbohydrates, protein, minerals, vitamins and dietary fibers, with relatively well-balanced amino acid profiles and a unique blend of bioactive compounds. Recent developments in feed processing technologies have improved the nutritional quality of animal feed products [2,7]. The global market for animal feed additives and nutritional supplements was valued at 54 billion USD in 2018 and is estimated to generate a net revenue of 64 billion USD by 2025, growing at a compound annual growth rate (CAGR) of $2.7 \%$. Worldwide, the animal nutrition market is largely driven by a rising demand for poultry feed, which constitutes about $47 \%$ of the total consumption [7].

There has been increasing interest in the market potential for functional feeds for livestock, with added-value linked to the health benefits for farm animals. Increasing consumer awareness regarding poultry meat quality, recent outbreaks associated with poultry diseases and the utilization of poultry meat and egg products as economical sources of protein are the major driving forces amplifying the animal feed additive market [8]. Worldwide, several seaweed companies, such as Aurora (Edmonds, WA), MBD (Melbourne, Australia), Alltech (Nicholasville, KY), Cellana (Kailua-Kona, HI), Ocean Harvest (County Galway, Ireland), Olmix (Bréhan, France), AquAgri (New Delhi, India) and ASL (NS, Canada), have been commercially producing high value seaweed-based commercial feed products for animal nutrition. These commercial products can potentially improve the health and performance of livestock animals with reduced investments in feed.

This review provides an overview of the utilization of various specific seaweeds as sustainable feed sources for poultry production. A detailed survey of seaweed-supplemented diets on growth, performance, gastrointestinal flora, disease, immunity and overall health of laying/broiler hens is presented. Conclusions drawn and potential future developments are also discussed, with the expectation that this review may open new opportunities to investigate enhanced exploitation for the potential of various, efficacious seaweeds, especially for sustainable growth in the poultry feed industry.

\section{Effects of Various Seaweeds on Poultry Production}

Collectively, the poultry industry has explored novel candidates of seaweeds as dietary supplements. A major goal of introducing supplements into the poultry diet is to enhance the efficacy of feed for the cost-effective production of commercially important meat and eggs, whilst also maintaining and/or improving poultry health.

The concept of using seaweeds in poultry diets has been the subject of considerable research over at least the past two decades in particular. In livestock feed, seaweeds function as sources of complex carbohydrates, with prebiotic activities and pigments and polyunsaturated fatty acids, which are known to be beneficial to animal health [9]. Multiple species of brown, green and red seaweeds, either alone or in combination, are already being commercially used in the U.S. and Canadian poultry markets. The chemical compositions of different seaweeds are indeed highly variable, being dependent on the species, time of collection and habitat, temperature and light intensity as well as nutrient concentrations in their habitat and seawater. Brown seaweeds contain a range of bioactive compounds; however, they generally have lower nutritional value than red and green seaweeds. Brown seaweeds are rich in minerals (14\%-35\% dry matter) and some can accumulate iodine over 30,000 times higher than that found in seawater (1500-8000 ppm vs. $0.05 \mathrm{ppm}$, respectively) [10]. Red seaweeds may be rich in proteins $(10 \%-50 \%$ dry matter) and contain lower levels of iodine $(0.03 \%-0.04 \%)[10,11]$. 
Green seaweeds such as Sea Lettuce (Ulva spp.) may contain higher amounts of proteins (up to 15\%) as compared to brown seaweeds. Green algae are rich in total fiber $(290-670 \mathrm{~g} / \mathrm{kg})$, with a high content of both soluble and insoluble fibers [12].

For the production of seaweed meal, the post-harvesting steps must be performed quickly in order to avoid contamination, primarily by molds. Seaweeds are usually dried and ground to fine particles (300 and $900 \mu \mathrm{m}$ ) for supplementation in poultry meals. Drying of seaweeds should not exceed $50-70{ }^{\circ} \mathrm{C}$ in order to protect the bioactivity of the functional metabolites contained therein $[13,14]$. The purported health benefits for the inclusion of seaweed meal in poultry diets are explained below.

\subsection{Broiler Health}

\subsubsection{Green Seaweeds}

The ubiquitous green seaweed Ulva spp. has been studied extensively as a substitutional feed ingredient in the diets of broiler chickens. The replacement of corn with 3.0\% U. lactuca in the diets of male broilers, from days 12-33 post-hatch, improved the yield of breast muscle and dressing percentage and showed a numeric improvement in body weight gain (BWG) for birds fed 3\% vs. $1 \%$. These enhancements were attributed to the availability of soluble fibers and essential sulphur-containing amino acids including methionine and cysteine [15]. Inclusion of 3.0\% U. lactuca significantly reduced abdominal fat (i.e., related to cholesterol and triglycerides) in treated birds. However, production parameters including feed intake (FI), BWG and feed conversion ratio (FCR) were the same in treated birds as in the control group. Lower inclusion levels of $U$. lactuca of up to $3 \%$ did not demonstrate toxic or anti-nutritive effects on broiler health [15]. However, the inclusion of $4 \%$ and $6 \%$ of $U$. rigida -as a prebiotic feed additive in a broiler diet was found to improve FI, FCR and mortality. In addition, blood serum total cholesterol and triglyceride levels were lower in Ulva-fed birds over the controls. Intestinal histo-morphology (Figure 1), including villi width, height, and length, was greater in birds fed U. rigida feed as compared to basal diets.

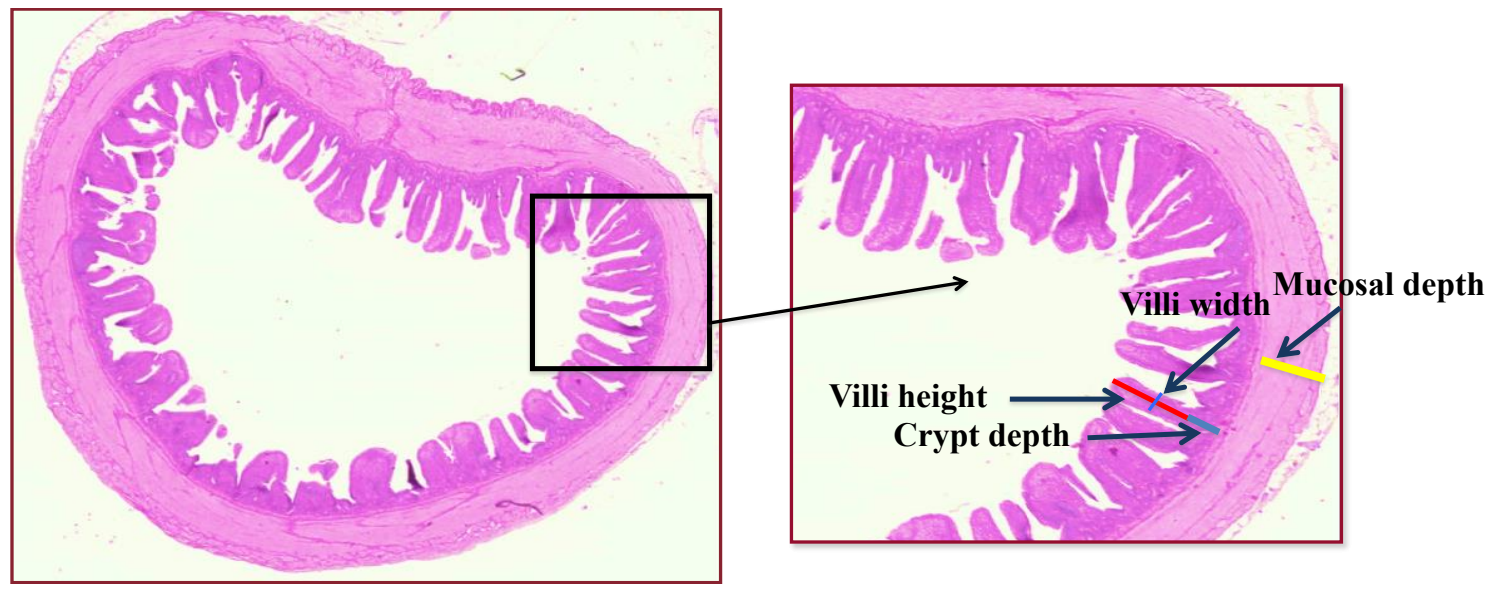

Figure 1. Histo-morphological parameters, including villi height, villi width, mucosal depth and crypt depth, for a histology section $(0.5 \mu \mathrm{m}$ thick, stained using haematoxylin and eosin staining using the procedure of Drury and Wallington (1980) and the Tissue-Tek ${ }^{\circledR}$ DRS ${ }^{\mathrm{TM}}$ (Sakura Finetek USA Inc., Torrance, CA, USA)) prepared at the ileocaecal junction region of the gastrointestinal tract (GIT) in a laying hen (Lohmann Brown Classic, 67 weeks) (Original figure by G.K.).

The prebiotic effects of $U$. rigida were similar to other prebiotic feed supplements including BIO-MOS ${ }^{\circledR}$ and inulin [16]. An increased intestinal villi length resulted in both a larger intestinal surface area and increased activity of the brush-border enzymes, leading to an increased surface area for absorption and digestive capacity [17]. Serum total cholesterol and triglyceride levels were significantly lower in Ulva treatments as compared to controls [17]. The differences in outcome of 
these studies with dietary inclusion of Ulva spp. may be attributed to factors such as the amount of seaweed supplemented, the purity of the seaweed, drying method, particle size, various methods of meal preparation and differences between species. All these variables should be considered in the construction of any seaweed-derived meal. However, it seems to be a common feature that levels of inclusion in the diet are generally low (up to $6 \%$ ). The seaweeds are not feed replacers in their own right, but they work (perhaps synergistically) to improve bird health and resistance to disease and, therefore, help them to grow faster, with better quality when added at lower rates as supplements or prebiotics.

\subsubsection{Brown Seaweeds}

Brown algae are rich in functional polysaccharides such as alginates and fucoidans, which are known to have various biological activities including anti-coagulant, anti-inflammatory, anti-viral and anti-tumoral properties. These seaweed components have been evaluated as feed additives to improve broiler performance. For example, by-products of the brown seaweed Undaria pinnatifida have been evaluated as a dietary supplement in broiler diets. Seaweed by-products, which are components of thalli (plant components that lack differentiation into distinct parts such as stem, leaves and roots) and which do not grow from an apical point, are not consumed as food. Brown seaweed by-products, at an inclusion level of $0.5 \%$ in broiler diet, resulted in higher BWG, improved blood serum profile, immune response and a reduced mortality rate as compared to a control diet [18]. Basal diet supplementation with 100 and $200 \mathrm{mg} / \mathrm{kg}$ of a fucoxanthin extract increased catalase (CAT), superoxide dismutase (SOD) activities and glutathione (GSH) levels and decreased malondialdehyde (MDA) levels in the liver, breast and drumstick tissues. These results were taken to demonstrate that fucoxanthins could be used to regulate the antioxidant metabolism and improve the immune system of broilers [19].

It is well documented that the antioxidant status of birds plays an important role in their resistance to various infections, maintenance of health and production and reproductive performance [20]. In another study, dietary supplementation with polymannuronate (a brown seaweed derivate), at inclusion levels of $0.1 \%, 0.2 \%, 0.3 \%$ and $0.4 \%$, altered the cecal microbiome, increased the concentration of lactic and acetic acid in the cecum and improved broiler chicken performance (i.e., average daily gain (ADG), FCR, antioxidant capacity and immune status) compared to the control diet [18]. This indicated that brown seaweed-derived compounds can improve the immune status, antioxidant capacity and performance of broiler chickens.

The addition of Ascophyllum nodosum (A. nodosum, $0.05 \%$ of feed) to broiler feed reduced the effect of prolonged heat stress while not negatively affecting growth and feed conversion, indicating that this type of feed supplementation can be used to improve bird welfare during heat stress events in poultry production [21]. Due to climatic change, meteorological events causing heat stress are of increasing occurrence. Moreover, poultry production is often carried out in regions of the globe where temperatures can reach $50^{\circ} \mathrm{C}$; the costs of cooling would be difficult to pass on with tight margins. Hence, the addition of $A$. nodosum at low inclusion levels in the diets of poultry birds can reduce the requirement (and therefore the associated cost) of cooling poultry barns, as well as the consequences of heat-associated increased mortality and lost production.

The nutritional value of various brown seaweeds of the genus Sargassum spp., applied in different formats including raw or thermally treated (i.e., boiled and autoclaved), were evaluated in broiler diets at $2 \%, 4 \%$ and $6 \%$ inclusion levels. However, the inclusion of raw or thermally treated seaweeds showed no significant effects on carcass characteristics. In contrast, the blood plasma profiles of treated birds were significantly altered, including elevated plasma high density lipoprotein (HDL) and reduced total cholesterol concentrations as compared to the control birds [22].

A recent study by Kumar (2018) demonstrated the effects of dietary supplementation of Sargassum wightii in broiler diets. Dried S. wightii powder at $1 \%, 2 \%, 3 \%$ and $4 \%$ improved BW, FI, FCR and meat quality of broilers. Dietary inclusion of $1 \%$ and $2 \%$ Sargassum reduced both blood plasma cholesterol and globulins and also improved total serum proteins, albumin, calcium, phosphorous and 
triglyceride levels in treated birds. Results from this study indicated that inclusion of $1 \%$ or $2 \%$ Sargassum powder had the optimal supplementation effects. Sargassum improved dietary palatability whilst resulting in higher FI and enhanced digestibility and intestinal absorption, leading to improved BWI, as compared to controls. A higher FCR subsequently improved meat quality and carcass yield in treated birds, leading to cost efficiency. Active ingredients from Sargassum, including saponins, hemicelluloses, mucilage, tannins and pectin, were implicated as altering blood low density lipoprotein (LDL)-cholesterol by inhibiting bile salts [23]. Beneficial effects in broilers might also be attributed to a rich content of minerals, vitamins, long-chain fatty acids, essential amino acids, sterols and fucoidans in S. wightii. The degree of enhancement of broiler performance with dietary inclusion of Sargassum supplement can be attributed to factors such as amount supplemented, the purity of the seaweeds used and differences in seaweed meal preparation (drying and particle size). Tasco ${ }^{\circledR}$, a branded product made simply from rapidly sun-dried A. nodosum, has been demonstrated as a prebiotic for broilers and can be used as an alternative to antibiotic growth promoters. Addition of Tasco ${ }^{\circledR}$ improved the growth and performance of broilers at very low inclusion levels $(0.25 \%$ and $0.5 \%)$, thus increasing its cost effectiveness (and enabling the use of the term "super-prebiotic"). Tasco ${ }^{\circledR}$ displayed improvements in growth comparable to the positive control inulin (a standard prebiotic derived from chicory) and the antibiotic virginiamycin. Tasco ${ }^{\circledR}$ showed effectiveness in the lower gastrointestinal tract (GIT) by altering the $\mathrm{pH}$ of the intestine, intestinal histo-morphology and bursa and cecal relative weights, indicating its fermentation in the lower GIT by beneficial microflora [24].

\subsubsection{Red Seaweeds}

Red seaweeds including Chondrus crispus (Irish moss) and Palmaria palmata (dulse) have high nutritive values and have been considered to be highly palatable to poultry and ruminant animals. Dried red seaweeds, e.g., Polysiphonia spp. (up to 3\%), were shown to serve as an intermediate source of protein to growing broiler chicks. Polysiphonia contains elevated levels of proteins (i.e., $32.4 \%$ ) and minerals as required by rapidly growing poultry. However, inclusion had no significant effect on overall growth performance [14]. Calcified seaweeds can function as an alternative source of dietary calcium, which resulted in increased bone health and reduced leg weakness and lameness as compared to calcium obtained from limestone. The inclusion of the calcareous marine algae (CMA, at $0.45 \%, 0.6 \%$, $0.75 \%$ and $0.9 \%$ ) reduced both feed intake and bird growth, with a negative impact on bone strength, since tibia ash and phosphorus levels were lower in birds fed with calcium $(0.9 \%)$ from CMA. However, ileal calcium digestibility had a linear increase in birds fed with $0.45 \%$ CMA [25]. Higher dietary calcium from limestone decreased phosphorous digestibility in broilers, which was shown to be improved by the inclusion of lower concentrations of calcified seaweeds [26,27]. Inclusion of P. palmata $(1.8 \%)$ in broiler diets improved body weight and increased beneficial bacteria (e.g., Lactobacillus) in the ileum, serum IgA and ileal villus width, height and surface area [28]. Feed supplementation with Kappaphycus alvarezii (AF-KWP) improved body weight gain and feed intake and increased the haemagglutination (HA) titre and cell-mediated immunity (CMI) levels. Inclusion of $1.25 \%$ AF-KWP in a broiler diet positively affected performance, immunity and breast yield in broiler chickens [29]. Dietary inclusion of the commercial red seaweed, dulse (P. palmata) (Organic Whole Leaf-Dulse, Vitaminsea ${ }^{\circledR}$ ) at $0.15 \%$ showed beneficial effects on growth performance, cooking loss, drip loss, diarrhea score and the fecal microbiome (i.e., it significantly reduced the relative abundance of pathogenic bacteria including E. coli and enhanced beneficial bacteria including Lactobacillus) [30]. A similar response of decreased "shedding" of intestinal E. coli O157:H7 was observed in beef cattle when sun-dried Ascophyllum nodosum seaweed (i.e., Tasco-14 ${ }^{\mathrm{TM}}$ ) was added to their diets. Administration of Tasco- $14^{\mathrm{TM}}$ at a level of $20 \mathrm{~g} / \mathrm{kg}$ diet for 7 days was effective at lowering both the duration and intensity of E. coli O157:H7 fecal shedding by cattle [31]. These beneficial effects can be due to the presence of dietary sulphated polysaccharides in seaweeds. Similarly, economically viable seaweeds can be administered to pre-slaughter chickens in order to evaluate reductions in the shedding of pathogenic bacteria. 


\subsection{Health of Laying Chickens}

\subsubsection{Green Seaweeds}

Ulva prolifera and Cladophora sp. are enriched in micro-elements including $\mathrm{Cu}(\mathrm{II}), \mathrm{Zn}(\mathrm{II}), \mathrm{Co}(\mathrm{II})$, $\mathrm{Mn}(\mathrm{II})$ and $\mathrm{Cr}(\mathrm{III})$, and improved the average body weight of treated laying hens, resulting in a higher average egg weight and eggshell thickness vs. the controls. Laying hen diets supplemented with seaweeds enriched with micro-elements also resulted in higher microelement transfer to eggs and enhanced the colour of yolk [32]. Inclusion of $U$. prolifera at 1\%, $2 \%$ and $3 \%$ improved immune function, egg production and egg quality (egg weight, shell thickness and yolk colour) whilst also reducing and/or improving the feed conversion ratio and yolk cholesterol. In addition, the abundance of beneficial microbes, including Bifidobacterium and Lactobacillus, was significantly increased in the feces of laying hens as compared to control groups, indicating better animal health [33]. Ulvan (i.e., a sulphated polysaccharide extract from the green seaweed $U l v a$ ), when added to diets of brown laying hens at $0.5 \%, 0.8 \%$ and $1 \%$, enhanced the function of the small intestine and regulated the digestive system, resulting in improved egg production, egg weight and FCR. This could be of great benefit to poultry farmers, as ulvan did not increase the feed intake but enhanced the egg weight [34]. It is possible that other sulphated polysaccharides (from brown and red seaweeds) have similar functionalities, but this remains to be investigated.

\subsubsection{Brown Seaweeds}

Incorporation of 10\% Macrocystis pyrifera (giant kelp) in meal enriched with n-3 FA from fish oil in the diets of 35-week-old Leghorn hens effectively increased egg n-3 FA content, albumen height and yolk colour [35]. Sensory evaluation of these eggs revealed that flavour was not affected by the treatment. In another study, the effects of different concentrations of brown algae (BMA, Sargassum dentifebium, 3\% and 6\%) prepared using different methods (i.e., sun-dried, SBMA; boiled, BBMA; autoclaved, ABMA) on egg profiles were reported. Inclusion of $3 \%$ or $6 \%$ BMA meal in the laying hen diet significantly reduced plasma cholesterol, as well as yolk cholesterol and triglycerides, whilst also improving the total palmitic acid, carotene, lutein and zeaxanthin levels in eggs [36]. By-products from Undaria pinnatifida and Hizikia fusiformis (0.5\%) were shown to improve egg laying performance and relative organ weights, particularly the liver and cecum, over those of the control group. This study demonstrated that supplementation with seaweed by-products resulted in superior bird health [37]. Dietary supplementation by the commercial brown seaweed Ascophyllum nodosum, trademark name $\operatorname{Tasco}^{\circledR}$ (at $0.25 \%$ and $0.5 \%$ ), significantly enhanced egg weight, shell weight and yolk colour in eggs from Lohmann Lite hens (age $=70$ weeks). Hens fed a diet with $0.25 \%$ Tasco ${ }^{\circledR}$ had significantly larger eggs and shell weight as compared to hens fed $0.5 \%$ and the control diets, indicating that lower inclusion levels of Tasco ${ }^{\circledR}$ enhanced both productivity and economic efficiency in poultry production [38].

\subsubsection{Red Seaweeds}

Inclusion of red seaweeds, e.g., Chondrus crispus (CC, 1\%) and Sarcodiotheca gaudichaudii (SG, 2\%), in standard poultry diets improved FCR and egg quality parameters. The SG and CC groups showed greater height and surface area of villi as compared to the control birds. Seaweed supplementation also increased the abundance of beneficial gut bacteria, e.g., Bifidobacterium longum (4-14-fold) and Streptococcus salivarius (4-15-fold), and reduced the prevalence of Clostridium perfringens. Additionally, the concentration of short chain fatty acids, including acetic acid, propionic acid, n-butyric acid and i-butyric acid, were significantly higher for both CC and SG treatments [39]. Gracilariopsis persica meal fed at $50 \mathrm{gm} / \mathrm{kg}(5 \%)$ significantly lowered the levels of cholesterol and malondialdehyde in egg yolk vs. control birds [40]. Dietary inclusion of the red seaweed Kappaphycus alvarezii (1.5\%) significantly reduced egg laying age and improved production parameters and egg quality traits (egg production, egg weight, shell thickness) in laying hens [41]. Taken together, these studies suggest that dietary 
supplementation with selected red seaweeds as a potential prebiotic source is associated with improved performance, egg quality and overall gut health in laying hens.

\section{Novel Formulations of Seaweeds for Poultry Health}

Processing/modification of seaweeds can improve the bioavailability of their active components in poultry feed, thereby impacting both the digestibility and performance of chickens. The following strategies have been reported to improve feed efficiency and palatability of seaweeds in livestock feed. The drying and pre-treatment phases are very important for the maintenance of seaweed quality during storage.

\subsection{Mechanical Approach}

Feed processing methods include drying, cooling, pelleting, cooking, vacuum coating, steam exploding and extruding. These processes are utilized in order to be cost-effective (provide target nutrient at least/best cost) and to improve digestibility and feed efficiency in chickens. Feed technology has advanced from basic mixing of a mash feed to more innovative preparations involving physical and hydrothermal processing operations. In a commercial setting, feed processing includes single or multiple processing of feedstuffs in order to meet objectives. Poultry diets are manufactured using a combination of technologies such as grinding with hammer and/or roller mills, along with hydrothermal processing including pelleting, expansion or extrusion. The major advantages of feed processing are the improved availability of nutrients, destruction of inhibitors and toxins and reduction of feed wastage [42].

\subsubsection{Size Reduction}

The particle size of feed in the diet plays an important role in the development of the digestive tract and regulation of feed intake by birds. Birds consuming larger particle-size feed develop larger, more muscular gizzards and longer intestines. In addition, larger feed particles require more time for breakdown in the gizzard and intestine (Figure 2), resulting in longer microvilli and an increase in surface area, thus positively affecting digestibility and absorption [43]. Raw seaweeds are mainly dried and ground to pass a $0.3-1.0 \mathrm{~mm}$ mesh screen using a Wiley mill or grinders. Size reduction by grinding is the most economical method utilized in poultry feed preparation.

\subsubsection{Extrusion}

Feed extrusion is a combination of heat, shear and compressional forces utilized to produce strongly bonded and porous pellets. Feed prepared by extrusion with Chondrus crispus $(0.5 \%-3 \%)$ had no effect on either egg quality or production parameters, indicating that minimal processing by simple grinding was satisfactory compared to the added cost of mechanical processing [38]. Birds fed on the 3\% Chondrus diet produced larger and heavier eggs, but no other significant differences were observed in $3 \%$ vs. $1 \%$ and/or $2 \%$ inclusion. Hence, the recommended levels of Chondrus crispus supplementation to laying hen feed were $1 \%-2 \%$, which is also more cost-effective. On the other hand, the recommended level of Tasco ${ }^{\circledR}$ (air dried, brown seaweed Ascophyllum nodosum) in laying hen feed was $0.25 \%$, which is predicted to be the most cost-effective.

\subsection{Additive/Synergistic Approaches}

\subsubsection{Biological Treatment by Fermentation}

In poultry, feed processing by fermentation can produce functional feeds which are formulated to improve the gut microbiome, health and performance. Major functional ingredients introduced by this treatment include higher numbers of lactic acid bacteria, a reduced $\mathrm{pH}$ and high concentrations of organic acids. These features protect the feed from microbial contamination during storage $[45,46]$. Fermentation enhances the antioxidant, anti-coagulant and anti-inflammatory effects of seaweeds, 
and it also increases the stability of feed during storage. In addition, beneficial microorganisms used in microbial fermentation can have probiotic effects on poultry performance. Thus, fermentation of seaweeds by probiotic bacterial strains could introduce synergistic effects [47]. Feed supplementation with fermented brown seaweeds, e.g., Undaria pinnatifida (0.5\%), improved the weight gain, feed: gain ratio and immune status of broiler chickens as compared to controls. Blood serum profiles including glutamic pyruvate transaminase (GPT) and concentrations of immunoglobulins (IgA and IgM) were significantly higher in fermented seaweed treatments than their controls. However, the IgG titers were decreased as compared to controls [18]. These observations indicated that fermentation of these dietary seaweeds by Bacillus subtilis improved the growth performance and immune profile in broilers [18]. Conversely, the same authors concluded that supplementation with fermented seaweeds had no beneficial effect on laying hen performance. Bacterial fermentation was proposed to result in depletion of oligosaccharides, which would decrease the positive supplementation effect of seaweeds as prebiotics [37]. Altering the conditions/environment during fermentation by adding acidifiers, e.g., organic acids, concentrated starter lactic acid bacteria (LAB) strains or enzymes, can speed up the fermentation processes as well as improve the functional characteristics and palatability of the final product [48]. With improved palatability, feed intake by chickens can be increased, leading to positive effects on growth performance, gut microbiome and morphology. Clearly, whilst promising, further work is required in this fledgling area of application.

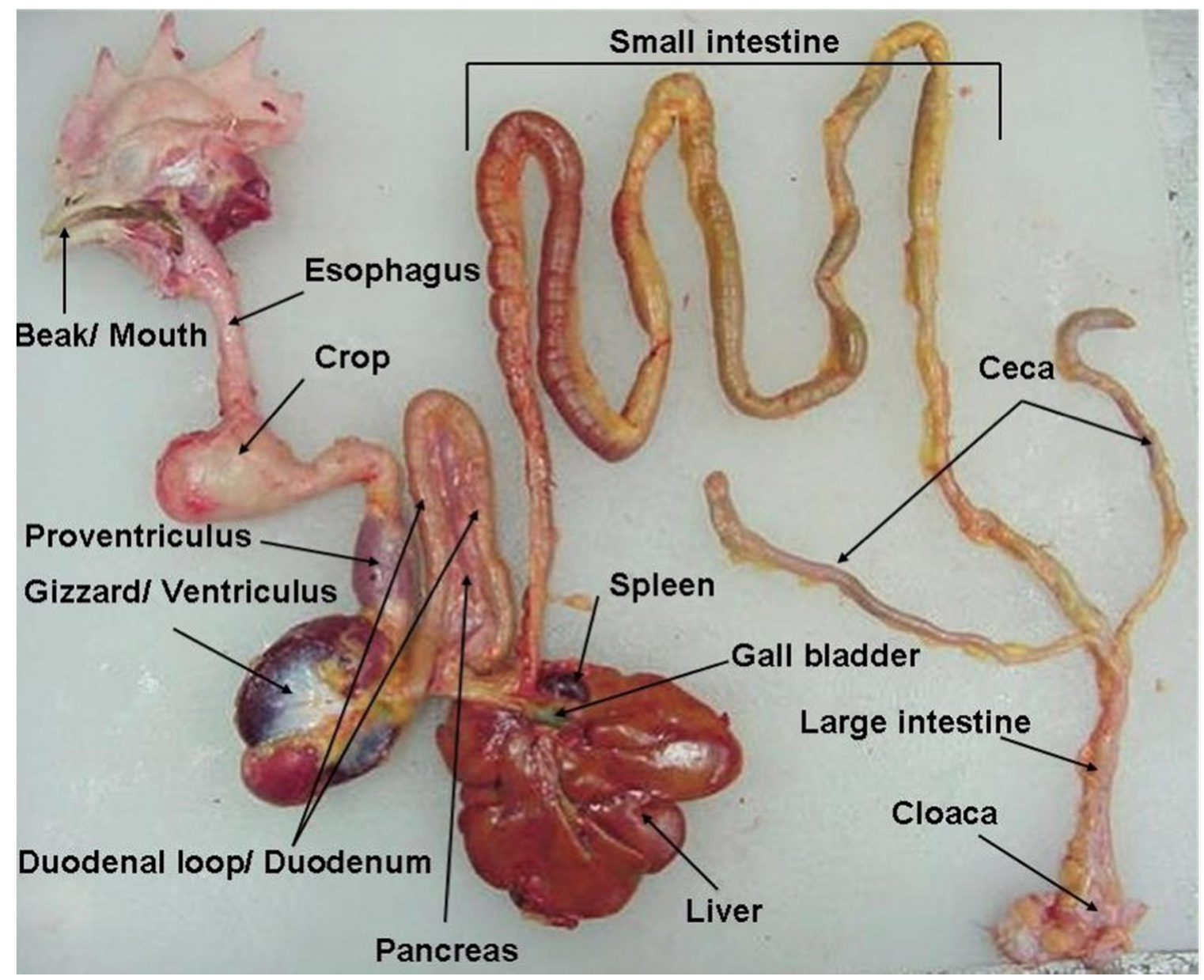

Figure 2. Diagrammatic representation of different parts of the digestive organs of a typical chicken. (adapted from [44]). 


\subsubsection{Botanical Blends}

Seaweeds can be used in combination with other natural bioactives including essential oils, green tea and anti-microbial peptides. Such combined products function as botanical alternatives to chemicals and antibiotics, for use in certifiably organic poultry production. For example, a combination of the green alga Ulva (cited as Enteromorpha) (10\%) and sardine oil (2\%) provided a source of antioxidants in the laying hen feed and also enhanced the DHA (docosahexaenoic acid) levels in eggs [49]. Similarly, the brown algae Macrocystis pyrifera and Sargassum sinicola (administered at 10\%) enhanced the EPA (eicosapentaenoic acid) content of the eggs. In general, eggs can be conserved at $4{ }^{\circ} \mathrm{C}$; however, the concentration of fatty acids declines with increasing storage time. The inclusion of sardine oil in the diets of laying hens was observed to increase the $n-3$ polyunsaturated fatty acids (PUFAs) content of eggs; however, $\mathrm{n}-3$ PUFAs are more sensitive to oxidation, resulting in rancidity in the final product and leading to reduced shelf life. [49]. Thus, it can be inferred that supplementation of laying hen diets by selected seaweeds, in combination with essential oils, can produce enriched eggs with improved shelf life. In another study, co-supplementation of a laying hen diet with green tea (at $0.1 \%$ and $0.2 \%$ ), combined with red and green seaweeds (also at $0.1 \%$ and $0.2 \%$ ), led to improved egg production, egg quality and physiological and immunological performance of late phase laying hens [50]. Co-supplementation with dietary Laminaria japonica (brown seaweed) powder $(3 \%)$ and anti-microbial peptide (300 mg cecropin $/ \mathrm{kg}, 0.03 \%$ ) significantly improved growth performance (i.e., increased FCR) and immune function (serum Newcastle disease antibody titers and lymphocyte numbers) in broilers. In addition, the same co-supplementation reduced E.coli and increased Lactobacillus levels in the cecum of broiler chickens, indicating the potential use of L. japonica powder and cecropin as an alternative to antibiotics in broiler production [51].

Algae-based antioxidant supplements containing selenium yeast (EconomasE ${ }^{\circledR}$, Alltech Inc., Nicholasville, KY, USA), when added to broiler diets, significantly improved the meat quality attributes, including water holding capacity, tenderness, colour and $\mathrm{pH}$; thus, EconomasE ${ }^{\circledR}$ can be used as a nutrient supplement in broiler diets [52]. Contamination by mycotoxins as a result of the spoilage of the feed results in undesirable health effects and a decline in the rate of egg production, with adverse economic effects. Hence, control of fungal development and mycotoxin production are critical for feed and animal producers. Addition of EconomasE ${ }^{\circledR}(2 \mathrm{gm} / \mathrm{Kg}, 0.2 \%)$ to mycotoxin-contaminated corn diet was demonstrated to partially improve the production performance (FCR) in broiler chickens [53]. Mycotoxins such as aflatoxins (AF), ochratoxin A (OTA), fumonisins (FUM), deoxynivalenol (DON) and T-2 toxin adversely affect the health and productivity of poultry. It was suggested, but not fully tested, that Tasco ${ }^{\circledR}$ or dried Ascophyllum meal could have mycotoxin-binding effects [53].

\subsubsection{Algal Clay}

Seaweed containing feed supplement MFeed $+{ }^{\circledR}$ Olmix, Brehan, France, has been developed by associating algal extracts (Ulva sp. and Solieria chordalis) with clay (bentonite) for use in livestock diets. Clays contain layered mineral materials organized in a succession of aluminum and silica-based sheets. Some seaweeds contain high levels of trace mineral ions (e.g., iron, zinc, copper, titanium) that can function as co-factors for enzymes and so improve their activities. Moreover, clay has been shown to slow down the transit time of feed in the intestine, thereby increasing digestion and resulting in better feed efficiency and nutrient uptake [54]. Such effects of clay have also been established in pigs [55].

In broilers, supplementation with a clay mix improved the weight gain and feed efficiency (feed intake and growth). Seaweeds in the clay mix introduced trace mineral ions into the diet, which improved the activity of some digestive enzymes and resulted in increased growth performance of the broilers fed on the supplemented diet. Algal clay $(0.1 \%)$ can be incorporated to reduce the cost of feed while still maintaining a productive performance in broilers [56]. An algal clay-based product (i.e., MT.X+ $+{ }^{\circledR}$, Olmix product) added to the diet prevented the negative effects of mycotoxin contamination on performance and productivity in broilers, at both experimental and commercial 
scales. The product improved the production efficiency factor by $10 \%$ and the return on feed cost by $36 \%$ when compared with the control [57].

In 2016, the European Food Safety Authority (EFSA) Panel on Additives and Products or Substances Used in Animal Feed (FEEDAP Panel) delivered a scientific opinion on the safety and efficacy of an algal/clay mix for animal consumption [58]. The panel concluded that the additive product, composed of feed-grade bentonite and selected seaweeds, was considered safe for livestock (e.g., piglets, cows and chickens) consumption, at a maximum recommended dose of $124 \mathrm{mg} / \mathrm{kg}(0.0124 \%)$ of complete feed. The additive product is considered non-genotoxic (bentonite is not absorbed from the gut lumen and the seaweeds were shown to have beneficial effects in humans) and were safe for animal nutrition and for consumers [58].

\section{Anti-Bacterial and Anti-Viral Effects of Various Seaweeds on Disease in Poultry Production}

The use of seaweeds as anti-infective agents in commercial livestock production has gained interest due to an increase in antibiotic-resistant bacterial strains and increasing consumer concerns regarding drug residues in animal meat. Seaweeds are a rich source of dietary fiber, minerals, vitamins, proteins, phlorotannins and carotenoids [59]. Seaweeds in poultry diets enhance gut microbiota, as the algal biomass remains mostly undigested in the lower GIT, and therefore act as substrates for bacterial fermentation [60]. Red and brown seaweeds have prebiotic-like properties that alter the metabolic activities of beneficial microflora and reduce the prevalence of pathogenic bacteria [61]. Moreover, a carbohydrate fraction extracted from the red seaweed Gracilaria persica exhibited direct anti-microbial effects against six bacterial pathogens including Staphylococcus aureus, E. coli, Methicillin-resistant Staphylococcus aureus (MRSA), Salmonella typhimurium, Pseudomonas aeruginosa and Aeromonas hydrophila and induced a humoral-immune response against sheep red blood cells (SRBC) [62]. Likewise, phlorotannin extracts isolated from two brown seaweeds A. nodosum and Fucus serratus were effective at killing three foodborne pathogens, E. coli O157, Salmonella agona, and Streptococcus suis, without negatively affecting the pig intestinal cells (in vitro) [63]. Water extracts of the red seaweeds Gelidium latifolium, Hypnea musciformis, Jania rubens, Jania spp. and Laurencia obtusa showed significant in vitro anti-microbial activities against pathogenic, Gram-negative bacteria, including E. coli, Klebsiella spp. and P. aeruginosa [64]. Moreover, sulphated galactans and carrageenans from an aqueous extract of the calcareous red alga Corallina sp. possessed bactericidal activity against pathogenic Gram-positive bacteria including Enterococcus faecalis and Staphylococcus epidermidis. Taken together, these studies indicate that the organic and polysaccharide fractions of selected red seaweeds can function directly as anti-microbial components in poultry diets. In addition, seaweed polysaccharides such as carrageenans, sulphated proteoglycans, and dextran sulphates have been reported to possess a broad spectrum of anti-viral activities [65-69]. A number of sulphated polysaccharides are potent inhibitors of paramyxoviruses, including parainfluenza virus, respiratory syncytial virus, mumps virus, measles virus, Newcastle disease virus (NDV) and distemper canine virus [68,70-73]. The aqueous extracts of the red alga Schizymenia dubyi with the highest sulphate content were effective in inhibiting HSV-1 replication at an $\mathrm{EC}_{50}=2.5-80 \mu \mathrm{g} / \mathrm{mL}$ without cytotoxic effects. Methanolic and 2,3,6-tribromo4,5-dihydroxybenzyl methyl (TDB) ether extracts isolated from the red alga Symphyocladia latiuscula exhibited anti-viral activities against wild type HSV-1 and acyclovir (ACV) resistant-HSV-1 ( IC $_{50}$ values of 5.48 , and $4.81 \mu \mathrm{g} / \mathrm{mL}$, respectively). Daily oral administration of the methanolic and TDB extracts delayed the appearance of lesions in infected mice, without toxicity [74]. Similarly, lambda-carrageenans from the red seaweed Gigartina skottsbergii (Gigartinaceae) displayed anti-viral activity against animal viruses belonging to the Alphaherpesvirinae sub-family BoHV-1 (bovine herpesvirus type 1) strain Cooper and SuHV-1 (suid herpes virus type 1) strain Bartha [75]. These results indicated that seaweed components, primarily polysaccharides, have potential as anti-viral agents in poultry diets. Table 1 describes recent studies of the use of various seaweeds as anti-microbial (bacterial, viral, plasmodial, etc.) in poultry diets in order to improve animal health and performance. 
Table 1. Use of seaweeds (SW) as anti-microbials in poultry diseases.

\begin{tabular}{|c|c|c|c|}
\hline $\begin{array}{c}\text { Macroalgae B = Brown } \\
R=\text { Red G = Green }\end{array}$ & $\begin{array}{l}\text { Level of Inclusion } \\
\text { in Feed }\end{array}$ & Anti-Microbial Response/Poultry Disease & Reference \\
\hline $\begin{array}{l}\text { Laminaria japonica }(\mathrm{LJP})(B) \\
\text { and anti-microbial peptide } \\
\text { cecropin }\end{array}$ & $\begin{array}{l}\text { Laminaria japonica } \\
\text { LJP:1\%, } 3 \% \text { and } 5 \% \\
\text { Cecropin: } 0.03 \%\end{array}$ & $\begin{array}{l}\text { Anti-bacterial and anti-viral activities were } \\
\text { observed with dietary supplementation of broiler } \\
\text { diets with LJP + cecropin, which increased feed } \\
\text { conversion ratio (FCR), and serum Newcastle } \\
\text { disease antibody titers and lymphocyte numbers. } \\
\text { In addition, birds fed with LJP showed } \\
\text { significant inhibition of E. coli counts and } \\
\text { increase in Lactobacillus counts in ceca. }\end{array}$ & [51] \\
\hline Ascophyllum nodosum (B) & $0.05 \%$ and $0.1 \%$ & $\begin{array}{l}\text { Anti-bacterial activity. } \\
\text { A. nodosum reduced C. jejuni counts in the } \\
\text { caecum of chicks ( } 10 \text { days old), at both } \\
\text { concentrations, but decreased the growth } \\
\text { parameters (disruptive effect on gut morphology } \\
\text { in ileum). Significant increases in the expression } \\
\text { of tight-junction genes OCLN and CLND-1 } \\
\text { alongside increases in MUC2 and } \\
\text { CCND1 expression. }\end{array}$ & [76] \\
\hline $\begin{array}{c}\text { Chondrus crispus and } \\
\text { Sarcodiotheca gaudichaudii (R) }\end{array}$ & $2 \%$ and $4 \%$ & $\begin{array}{l}\text { Anti-bacterial activity. } \\
\text { The incorporation of SW in the diets of Lohmann } \\
\text { Lite laying hens reduced the negative effects of } \\
\text { Salmonella enteritidis (SE) infection on body } \\
\text { weight and egg production. }\end{array}$ & [77] \\
\hline $\begin{array}{c}\text { Grateloupia filicina, (R) Ulva } \\
\text { pertusa }(\mathrm{G}) \text { and Sargassum } \\
\text { qingdaoense (B) }\end{array}$ & $\begin{array}{l}\text { In vitro, } 20-500 \mathrm{mg} / \mathrm{mL} \\
\text { of sulphated } \\
\text { polysaccharides SPs; } \\
\text { in vivo mouse model, } \\
0.001 \% \text { and } 0.005 \% \text { of } \\
\text { SPs per day }\end{array}$ & $\begin{array}{l}\text { Anti-viral activity. } \\
\text { Sulphated polysaccharide extracts from all three } \\
\text { species showed immune-modulatory activities, } \\
\text { both in vitro and in vivo; S. qingdaoense showed } \\
\text { the best activity. All three SPs significantly } \\
\text { inhibited the activity of activated AIV } \\
\text { (H9N2 subtype) in vitro and inactivated avian } \\
\text { influenza virus (AIV) in vivo. Sulphated } \\
\text { polysaccharides from G. filicina showed the } \\
\text { strongest anti-AIV response. }\end{array}$ & [78] \\
\hline $\begin{array}{l}\text { Ulva clathrata }(\mathrm{G}) \text { and } \\
\text { fucoidan }\end{array}$ & $\begin{array}{c}\text { In vitro } \\
0.1-1000 \mu \mathrm{g} / \mathrm{mL}\end{array}$ & $\begin{array}{l}\text { Anti-viral activity. } \\
\text { The ulvan and fucoidan extracts inhibited } \\
\text { Newcastle disease virus (NDV) in vitro and } \\
\text { showed no cytotoxicity at effective } \\
\text { concentrations. Ulvan inhibited viral fusion by } \\
\text { interacting with the intact F0 protein. } \\
\text { Ulvan exhibited better anti-cell-cell spread } \\
\text { activity than fucoidans, but a combination } \\
\text { showed more potent (synergistic) responses. }\end{array}$ & [79] \\
\hline $\begin{array}{l}\text { Highly soluble calcified } \\
\text { seaweed (HSC) (R) }\end{array}$ & $0.6 \%$ and $0.9 \%$ & $\begin{array}{l}\text { Anti-bacterial activity. } \\
\text { Broilers fed HSC diets had significantly higher } \\
\text { feed conversion/total weight than control birds. } \\
\text { Lower dietary Ca ( } 0.6 \% \text { vs. } 0.9 \% \text { ) showed lower } \\
\text { mortality associated with necrotic enteritis (NE) } \\
\text { as compared to higher dose }(0.9 \%) \text { and on } \\
\text { bird performance. }\end{array}$ & [80] \\
\hline $\begin{array}{l}\text { Chaetomorpha antennina }(\mathrm{G}) \\
\text { in combination with } \\
\text { mangrove species } \\
\text { Aegiceras corniculatum } \\
\text { (land plant) }\end{array}$ & $\begin{array}{l}\text { In vitro: } 0.5,1.0 \text { and } \\
1.5 \mathrm{mg} / \mathrm{mL} \\
\text { In vivo rat model: } \\
0.02 \% \text { per day }\end{array}$ & $\begin{array}{l}\text { Parasite inhibition. } \\
\text { The extract mixture showed } 60 \% \text { suppression of } \\
\text { parasitaemia against Plasmodium falciparum at } \\
1.5 \mathrm{mg} / \mathrm{mL} \text {. Anti-plasmodial activity }(50 \%) \\
\text { against Plasmodium berghei was observed in vivo. }\end{array}$ & [81] \\
\hline
\end{tabular}

\subsection{Mechanism of Anti-Microbial Activity of Seaweeds}

\subsubsection{Anti-Bacterial Mode of Action}

Seaweeds are continuously exposed to a range of abiotic stresses such as desiccation, sunlight, osmotic stress and extreme temperatures, as well as pathogenic microbes. In response, seaweeds have 
developed protective mechanisms in order to combat and survive these stressful conditions [82]. They produce an array of unique bioactive compounds, including sulphated polysaccharides, organic acids, pigments and phenolic compounds, which are responsible for a range of functionalities, such as antioxidant, anti-microbial and anti-viral activities. For example, phenolic compounds exhibit anti-microbial activity by permeabilizing the bacterial cell wall and releasing the intracellular contents [83]. Other mechanisms of action of phenolic compounds against bacteria include interference with nutrient uptake, impairment of protein and nucleic acid synthesis and disruption of electron transport chains [83]. On the other hand, seaweed-derived polysaccharides can elicit defense responses in the host which are similar to pathogen recognition (PAMP triggered immunity) [84]. Red seaweed-derived polysaccharides also exhibit anti-microbial activity because of their affinities towards surface appendages of the bacteria. Anti-microbial activities of red seaweeds and their extracted compounds on the poultry pathogen Salmonella Enteritidis (SE) have been linked with the down-regulation of virulence factors, restricted motility and flagellar functions and also direct the blockage of bacterial quorum sensing (Figure 3). Quorum sensing molecules such as auto-inducers (acylated homoserine lactones, AHL) have been shown to facilitate virulence, motility and biofilm formation in bacterial pathogens including Salmonella $[85,86]$. Previous studies have shown that some red seaweeds contain quorum sensing inhibitors, such as brominated furanones, which are capable of inhibiting bacterial biofilm formation and the regulation of flagellar and virulence genes, resulting in bacterial growth inhibition $[87,88]$.

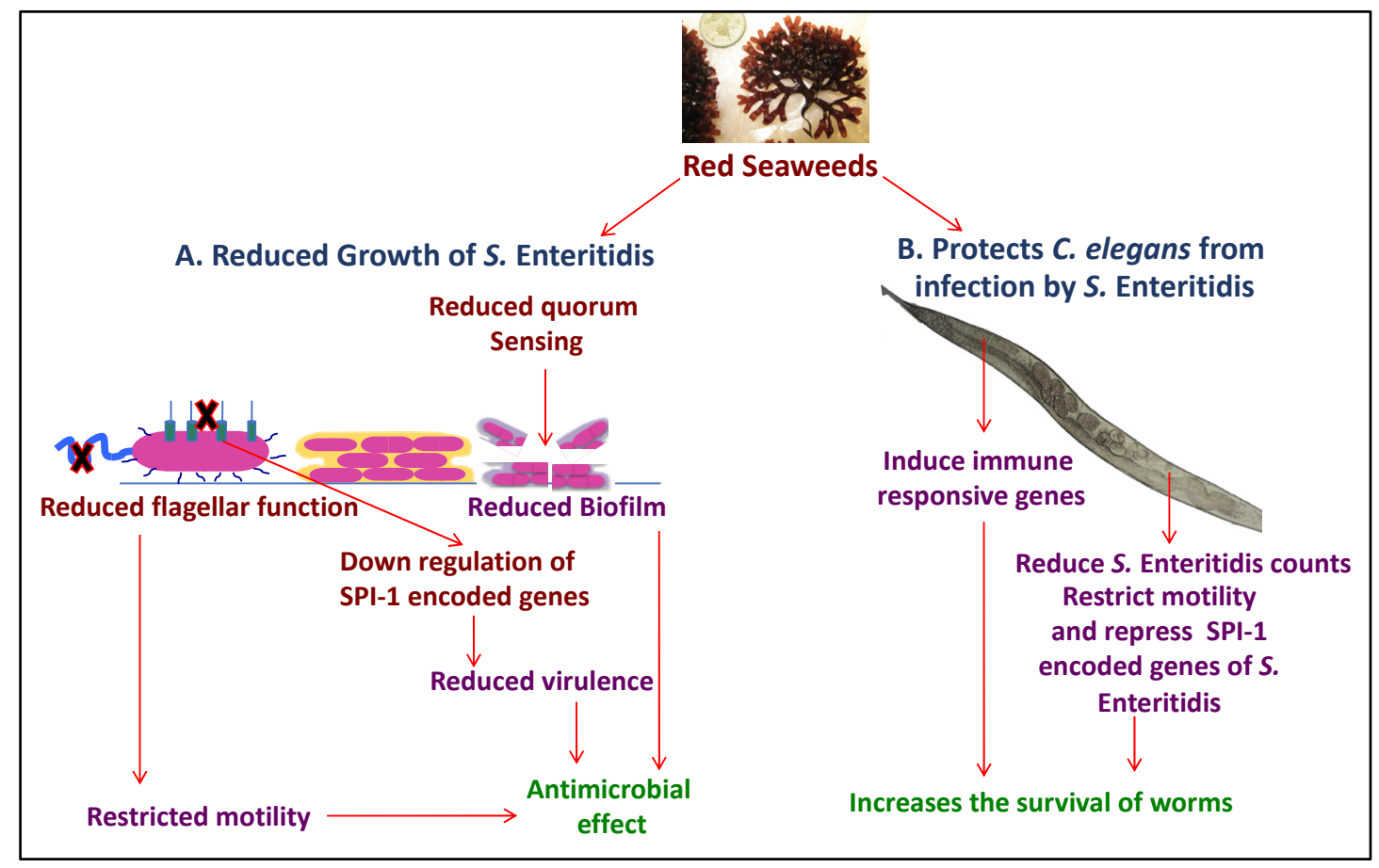

Figure 3. Illustration of modes of actions of selected red seaweeds, Chondrus crispus (CC) and Sarcodiotheca gaudichaudii (SG). A. Direct anti-microbial effect: red algal extracts inhibited growth, motility, biofilm formation and quorum sensing mechanisms in Salmonella Enteritidis. B. Protection of Caenorhabditis elegans from infection by $S$. Enteritidis: both red seaweed extracts increased the survival of infected worms by reducing $S$. Enteritidis colonization in Caenorhabditis elegans and enhancing the immune response of the worms (redesigned from [89]).

Yeast cell wall-derived mannan polysaccharides have been shown to deactivate Gram-negative pathogens such as E. coli and Salmonella by competitively binding to surface appendages such as the fimbriae and flagella. In the intestine, the adherence of pathogens to polysaccharides such as mannans reduces their ability to attach to epithelial cells, which results in the complete clearance of 
pathogenic bacteria from the gut without colonization [90]. Seaweed polysaccharides, with their ionic properties, have been shown to exhibit anti-bacterial activity against Gram-negative bacteria. For example, the anti-microbial activity of alginic acid (from brown seaweeds) against $E$. coli has been attributed to its polyanionic nature [91].

Another mechanism by which red seaweeds reduce the colonization of $S$. Enteritidis in the ceca of laying hens has been attributed to the attenuation of the virulence factors of SE (Figure 4). One study demonstrated that $C$. crispus (CC) and S. gaudichaudii (SG) water extracts reduced the relative expression of virulence factors of $\mathrm{SE}$ in vitro and decreased the colony count of SE in the intestine of C. elegans. Water extracts of seaweeds (CC and SG) significantly increased the survival of $C$. elegans infected with SE and reduced the accumulation of SE in C. elegans gut. A decrease in the colonization of SE in C. elegans was likely due to (i) a significant reduction in expression of virulence-associated genes of SE; (ii) reduced ability of bacteria to attach to the surface of the intestinal epithelium of C. elegans; (iii) induced immune response related genes of infected C. elegans. The modes of action of these red seaweeds to reduce Salmonella colonization in the model organism (C. elegans) were also effective when added to the feed of laying hens. The virulence factors of $S$. Enteritidis, which are known to be essential for the colonization of the intestinal tract in C. elegans, can be critical for SE colonization in poultry [92].

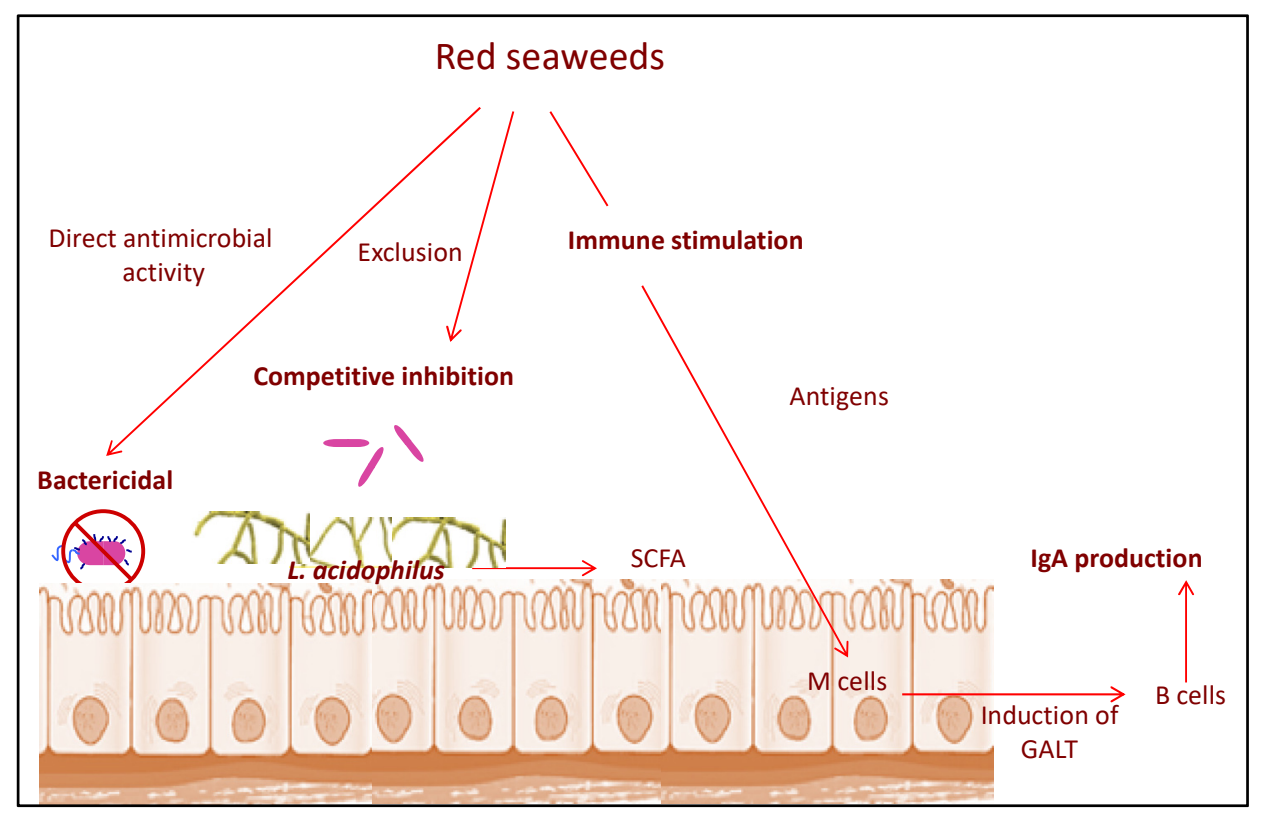

Figure 4. Dietary inclusion of red seaweeds in laying hen diets was observed to suppress the negative effect of SE on laying hen growth and performance. Various mechanisms included direct inhibition (bactericidal) of bacterial colonization of feces and ceca, competitive exclusion (i.e., reduction of $E$. coli titers) by beneficial bacteria such as Lactobacillus acidophilus and immune stimulation. SCFA: short chain fatty acid; GALT: gut-associated lymphoid tissue (Original figure by G.K.).

\subsubsection{Anti-Viral Modes of Action}

Polysaccharides and other bioactive functional molecules in seaweeds display anti-viral activity against a range of viruses by interfering with different stages of viral attachment, penetration and infection (Figure 5). Seaweed polysaccharides, such as carrageenans and galactans from red seaweeds, target viral attachment stages by either directly interacting with the virion or mimicking the binding of virus associated proteins (VAP) to the respective receptors [75,93]. Moreover, marine polysaccharides can also block the allosteric processing of the viral capsid during the internalization process and uncoating of the virus. For example, carrageenans inhibit viral attachment as well as its internalization and uncoating; ulvans inhibited fusion of Newcastle disease virus by blocking the cleavage of intact protein F0 into the mature form [79]; fucoidans inhibited viral infection by direct interaction with 
envelope glycoproteins [71]. Seaweed polysaccharides can also improve the host anti-viral immune response; for example, fucoidan can stimulate both specific and non-specific responses such as the activation of NK cells, maturation of dendritic cells (DCs) and activity of cytotoxic lymphocytes, as well as the ability to produce antigen-specific antibodies and memory $\mathrm{T}$ cells under in vitro and in vivo conditions [94].

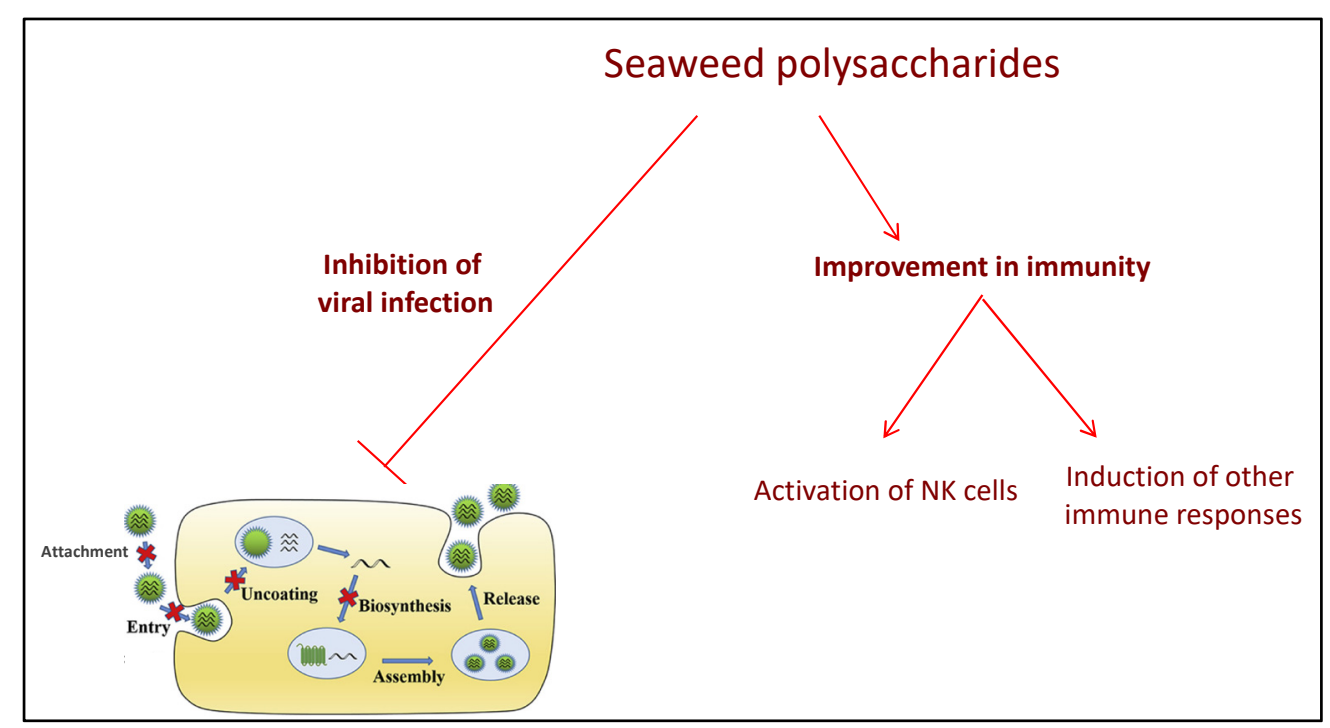

Figure 5. Mechanisms of anti-viral inhibition by seaweed polysaccharides. Seaweed polysaccharides display anti-viral activity against a range of viruses by interfering with different stages of viral attachment and replication as well as by improving host immunity (redesigned from [95]).

\section{Use of Prebiotics in Poultry Production}

The term prebiotics is defined as "a non-digestible food ingredient that affects the host by selectively stimulating the growth and/or activity of one, or a limited number of bacteria, in the colon" [96-98]. From a food safety perspective, prebiotics function as preventative agents which can modulate gastrointestinal microbiota in order to benefit the host and serve as a barrier to pathogen colonization. In poultry, prebiotics can induce a direct effect on birds by priming the host immune system or an indirect effect by modulating the compositing and fermentation profile of the gastrointestinal microbes [99]. Seaweeds must satisfy a number of criteria in order to be considered a prebiotic source:

(1) They should resist digestion by acid and enzymatic hydrolysis in the upper gastrointestinal tract (GIT).

(2) They must have a selective function as a substrate for the growth of beneficial bacteria.

(3) They must be capable of altering the profile of the microflora.

(4) They must induce beneficial effects that boost the host immune system and overall health.

Seaweeds and their bioactive compounds, such as polysaccharides and phenolics, exhibit these characteristics and can be considered prebiotic dietary supplements with gut health benefits. In poultry, prebiotics have been shown to improve gastrointestinal health by providing a substrate for beneficial bacteria within the gut microbiota of chickens [100]. The mode of action of most of prebiotics is by one or more of the following mechanisms: lactic acid production, inhibiting/preventing colonization of pathogens, modifying metabolic activity of normal intestinal flora and stimulation of the immune system [101]. Major beneficial probiotic bacteria present in the gut microbiome of chickens include Bifidobacteria, Lactobacillus, Ruminococcus and Streptococcus. These bacteria, which are present in the small intestine, utilize non-digestible polysaccharides and fibers for energy [102]. These beneficial bacteria can utilize seaweed polysaccharides and dietary fibers for energy and modulate the population of disease-causing bacteria in order to improve metabolism (Figure 6). 


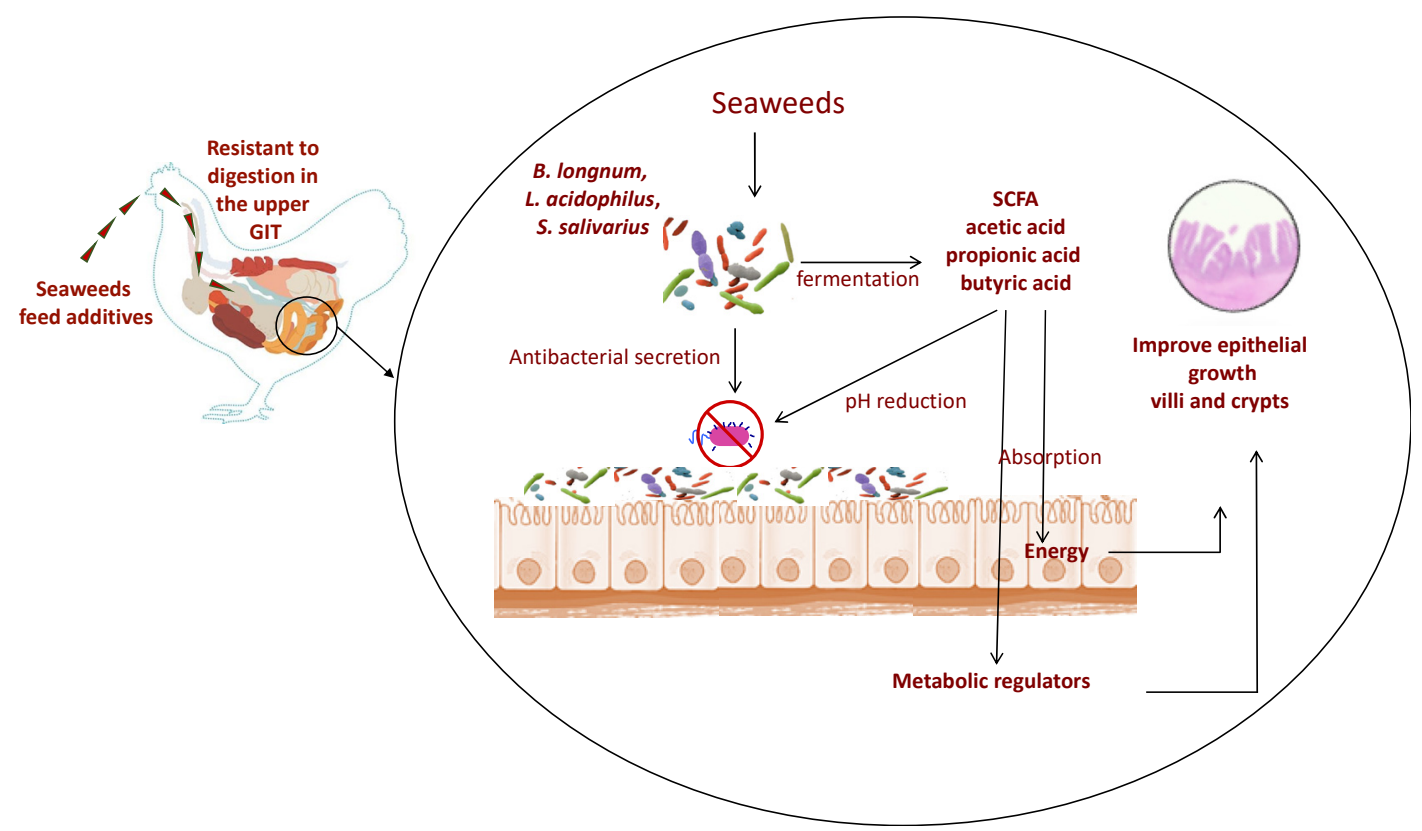

Figure 6. Modes of action of selected seaweeds as prebiotics for poultry health. Seaweeds are resistant to digestion in the upper gastrointestinal tract of chickens. After entering the colon, they are selectively fermented by beneficial microbiota, resulting in their increased numbers as well as the reduction of pathogenic bacteria by competitive exclusion. Beneficial microbes are known to produce short chain fatty acids and secrete anti-microbial peptides such as bacteriocins whilst also helping in the differentiation and proliferation of enterocytes, all of which improves epithelial growth in addition to exhibiting immunomodulatory effects (redesigned from [89]).

\section{Effect of Selected Seaweeds on the Gut Microbiome}

The gastrointestinal tract (GIT) of chickens possesses a diverse bacterial population which varies significantly from the proximal to distal segments. Bacterial abundance in a specific section of the GIT depends on their affinity to either enterocytes or to the mucus layer, tolerance to the GIT environment and also their resistance to the host immune system. Additional factors including the rate of passage of digesta, $\mathrm{pH}$, nutrient digestibility and bioavailability and the presence of anti-microbial peptides can modulate bacterial diversity in each segment of the GIT [103]. Dietary fibers and carbohydrates present in some seaweeds enhance the growth of certain beneficial bacteria, which leads to a cascade of biological functions which then impart beneficial effects on the health and growth of the host. Gut microbial fermentation of seaweed components, and their effects on the microbiome and metabolomics, are presented in Table 2.

Various seaweed polysaccharides, including ulvans and mannans from green, fucoidans and laminarans from brown and carrageenans from red seaweeds have been associated with a range of health-promoting effects, such as prebiotic, anti-bacterial, anti-inflammatory and antioxidant functionalities. These polysaccharides are neither digested nor absorbed by the host, but they serve as a substrate for bacterial fermentation in the colon and thus impart beneficial effects on both animal and human health [104]. 
Table 2. Summary of prebiotic effects of different seaweed dietary fibers (in vitro and in vivo), including modulation of the gut microbiome and fermentation response.

\begin{tabular}{|c|c|c|c|c|c|c|}
\hline $\begin{array}{l}\text { Seaweed Source } \\
\text { Red (R), Brown (B) } \\
\text { or Green (G) }\end{array}$ & Component & $\begin{array}{c}\text { Type of Study/Level of } \\
\text { Inclusion }\end{array}$ & Microbiome Modulation & $\begin{array}{l}\text { Metabolome } \\
\text { Modulation }\end{array}$ & Other Responses & Reference \\
\hline Palmaria palmata (R) & $\begin{array}{l}\text { whole } \\
\text { seaweed }\end{array}$ & $\begin{array}{c}0.6 \%, 1.2 \%, 1.8 \%, 2.4 \% \\
\text { and } 3 \% . \\
\text { In vitro in broiler } \\
\text { chickens }\end{array}$ & $\begin{array}{c}\text { Method: Microbiology culture } \\
\text { techniques, 16SRNA amplicon } \\
\text { sequencing. } \\
\uparrow \text { Bifidobacterium } \\
\uparrow \text { Lactobacillus (ileum) } \\
\downarrow \text { Clostridium perfringens }\end{array}$ & Not measured & $\begin{array}{l}\text { Increasing trend in the size } \\
\text { of villus height, width, } \\
\text { villus surface area and } \\
\text { mucosal depth } \\
\uparrow \text { Plasma immunoglobulin } \\
\text { (IgA and IgG) } \\
\text { Best response: } 1.8 \%\end{array}$ & [28] \\
\hline $\begin{array}{l}\text { Chondrus crispus and } \\
\text { Sarcodiotheca } \\
\text { gaudichaudii (R) }\end{array}$ & $\begin{array}{l}\text { whole } \\
\text { seaweed }\end{array}$ & $0.5 \%, 1 \%$ and $2 \%$ & $\begin{array}{c}\text { Method: Real-time PCR. } \\
\uparrow \text { Bifidobacterium longum, } \uparrow \text { Lactobacillus } \\
\text { acidophilus } \uparrow \text { Streptococcus salivarius } \\
\downarrow \text { Clostridium perfringens }\end{array}$ & $\begin{array}{c}\uparrow \text { Acetic, } \uparrow \text { propionic } \\
\text { acid, } \uparrow n \text {-butyric acid } \\
\uparrow i \text {-butyric }\end{array}$ & $\begin{array}{l}\text { Increase in the size of villus } \\
\text { height, width, villus surface } \\
\text { area and mucosal depth } \\
\text { Increase in ceca weight }\end{array}$ & [39] \\
\hline $\begin{array}{l}\text { Chondrus crispus and } \\
\text { Sarcodiotheca } \\
\text { gaudichaudii (R) }\end{array}$ & whole seaweeds & $2 \%$ and $4 \%$ & $\begin{array}{l}\text { Method: Microbiology culture } \\
\text { techniques, 16SRNA amplicon } \\
\text { sequencing. } \\
\uparrow \text { Firmicutes and Bacteroidetes } \\
\uparrow \text { Bifidobacterium longum, } \uparrow \text { Lactobacillus } \\
\text { acidophilus, } \uparrow \text { Streptococcus salivarius } \\
\downarrow \text { Clostridium perfringens } \\
\downarrow \text { Salmonella Enteritidis }\end{array}$ & $\uparrow$ Propionic acid & $\begin{array}{l}\uparrow \text { Plasma immunoglobulin } \\
\text { (IgA and IgG) }\end{array}$ & [77] \\
\hline Chondrus crispus (R) & whole seaweeds & $\begin{array}{c}0.5 \text { and } 2.5 \% \\
\text { In vivo mouse model }\end{array}$ & $\begin{array}{c}\text { Method: } 16 \mathrm{~S} \text { rRNA sequencing-based } \\
\text { Phylochip array of fecal samples. } \\
\uparrow \text { Bifidobacterium breve } \\
\downarrow \text { Clostridium septicum and } \\
\text { Streptococcus pneumonia }\end{array}$ & $\begin{array}{c}\uparrow \text { Acetic, } \uparrow \text { propionic } \\
\text { and } \uparrow \text { butyric acids in } \\
\text { faecal samples }\end{array}$ & $\begin{array}{l}\text { Improvements in proximal } \\
\text { colon histo-morphology } \\
\uparrow \text { Plasma immunoglobulin } \\
\text { (IgA and IgG) }\end{array}$ & [105] \\
\hline $\begin{array}{l}\text { Gracilaria spp. (R), } \\
\text { Gelidium sesquipidale } \\
\text { (R) and Ascophyllum } \\
\text { nodosum (B) }\end{array}$ & agar and alginate & Anaerobic fermentation & $\begin{array}{l}\text { Method: Fluorescent in-situ } \\
\text { hybridization. } \\
\uparrow \text { Bifidogenic effect }\end{array}$ & $\uparrow$ Acetic, propionic & Not measured & [106] \\
\hline
\end{tabular}


Table 2. Cont.

\begin{tabular}{|c|c|c|c|c|c|c|}
\hline Red seaweed & $\begin{array}{l}\text { neo-agaro- } \\
\text { oligosaccharides } \\
\text { (NAOS) from } \\
\text { enzymatic } \\
\text { hydrolysis of agarose }\end{array}$ & $\begin{array}{c}2.5 \% \text { and } 5 \% \\
\text { In vivo mouse model }\end{array}$ & $\begin{array}{c}\text { Method: Microbiology culture } \\
\text { techniques using cecal and fecal samples. } \\
\uparrow \text { Bifidobacteria and } \uparrow \text { Lactobacilli } \\
\text { Reduced putrefactive microorganisms. }\end{array}$ & Not measured & $\begin{array}{l}\text { No side effects, such as } \\
\text { eructation and bloating, } \\
\text { were observed }\end{array}$ & [107] \\
\hline $\begin{array}{l}\text { Saccharina (Laminiaria) } \\
\text { japonica }(\mathrm{B})\end{array}$ & alginate & $\begin{array}{c}4 \mathrm{mg} / \mathrm{mL}, \\
\text { simulated oral, gastric } \\
\text { and small intestinal } \\
\text { digestion }\end{array}$ & $\begin{array}{l}\text { Method: 16S rRNA sequencing-based } \\
\text { high throughput sequencing, } \\
\text { MALDI-TOF/MS. } \\
\text { Bacteroides (Bacteroides finegoldii) }\end{array}$ & $\begin{array}{c}\uparrow \text { Acetic acid and } \\
\uparrow \text { propionic acid }\end{array}$ & $\begin{array}{l}\text { Specific modulation of } \\
\text { Bacteroides by alginates }\end{array}$ & [108] \\
\hline $\begin{array}{l}\text { Eisenia bicyclis } \\
\text { (B) }\end{array}$ & laminarin & $\begin{array}{c}2 \%(w / w) \\
\text { In vivo in rats }\end{array}$ & $\begin{array}{c}\text { Method: } 16 \text { S rDNA-DGGE and } \\
\text { Pyrosequencing. } \\
\uparrow \text { Catabacter hongkongensis } \\
\uparrow \text { Stomatobaculum longum } \\
\downarrow \text { Adlercreuzia } \\
\downarrow \text { Helicobacter }\end{array}$ & $\downarrow$ Indole & Not measured & [109] \\
\hline $\begin{array}{l}\text { Ascophyllum nodosum } \\
\text { and Laminaria japonica }\end{array}$ & Fucoidan & $\begin{array}{l}0.01 \% \text { day }^{-1} \\
\text { In vivo in mice }\end{array}$ & $\begin{array}{c}\text { Method: } 16 \mathrm{~S} \text { rRNA sequencing-based } \\
\text { high throughput sequencing. } \\
\uparrow \text { Lactobacillus } \\
\uparrow \text { Ruminococcaceae } \\
\downarrow \text { Peptococcus }\end{array}$ & Not measured & $\begin{array}{l}\text { Reduced the antigen load } \\
\text { and the inflammatory } \\
\text { response }\end{array}$ & [110] \\
\hline Ecklonia radiata (B) & $\begin{array}{l}\text { Whole seaweed } \\
\text { and polysaccharide } \\
\text { fraction (fucoidan } \\
\text { and alginate) }\end{array}$ & $\begin{array}{c}5 \%(w / w) \text { WS } \\
5 \%(w / w) \text { PF in vivo } \\
\text { in rats }\end{array}$ & $\begin{array}{c}\text { Method: Real time Q-PCR. } \\
\uparrow F . \text { prausnitzii } \\
\uparrow E . \text { coli (PF) } \\
\downarrow \text { Enterococcus (WS) } \\
\downarrow \text { Lactobacillus } \downarrow \text { Bifidobacterium } \\
\downarrow \text { Firmicutes: Bacteroidetes }\end{array}$ & $\begin{array}{c}\uparrow \text { Acetate } \\
\uparrow \text { Propionate } \\
\uparrow \text { Butyrate (PF) } \\
\downarrow \text { Valerate } \\
\downarrow \text { Hexanoate } \\
\uparrow \text { Total SCFA } \\
\downarrow \text { i-Butyrate } \\
\downarrow \text { i-Valerate } \\
\downarrow \text { phenol } \downarrow \text { p-cresol }\end{array}$ & $\begin{array}{l}\uparrow \text { Butyrate (PF) } \\
\text { Linked to } \\
\text { anti-inflammatory action }\end{array}$ & [111] \\
\hline
\end{tabular}




\section{Reduced Use of Antibiotics in Combination with Dietary Seaweeds}

Antibiotics have been used as therapeutics for the treatment of animal and human diseases, as prophylactics to prevent infection and as growth promoters in livestock production [112]. Sub-therapeutic levels of antibiotics (i.e., $<200 \mathrm{~g} /$ ton of feed) have been included in animal diets in order to achieve growth promoting effects (U.S. Food and Drug Administration, 2000). The selection pressure on gut microbes caused by routine use of antibiotics has promoted the development of resistance genes that are capable of horizontal gene transfer between different species of pathogenic bacteria. This unfortunate situation has resulted in the uncontrolled multiplication of resistant bacterial pathogens including Clostridium, Salmonella, and Campylobacter, which can cause harmful diseases in the host. In addition, alterations in the microbiome within the host gut can lead to a predisposition to infection by other environmental pathogens [113]. In the United States, the Food and Drug Administration's Center for Veterinary Medicine (CVM) has developed a five-year action plan (2018-23) for supporting anti-microbial stewardship in veterinary settings in order to limit or reverse bacterial resistance due to the overuse of antibiotics in food-producing animals. FDA/CVM has set limits on the use of cephalosporin and has withdrawn approval for the use of fluoroquinolones in poultry, because these antibiotics are also commonly used in human medical treatments. In North America and Europe, there is a heightened public awareness of the negative effect of antibiotics in livestock production and an increasing scientific and regulatory interest in developing alternatives to antibiotics [114]. However, in developing countries, the use of antibiotics in animal production is unregulated. This has resulted in sky-rocketing levels of anti-microbial resistance in many jurisdictions and increasingly worldwide.

The growing demand for animal protein in developing countries has resulted in a dramatic increase in the administration of antibiotics to livestock [115]. Since 2000, the demand for protein from meat plateaued in developed countries but grew significantly in developing countries, i.e., $68 \%$ in Asia, $64 \%$ in Africa and $40 \%$ in South America. An increase in animal production has resulted in increased frequencies of infectious disease outbreaks within flocks and tripled the occurrence of antibiotic resistant, zoonotic bacteria (E. coli, Campylobacter, Salmonella and Staphylococcus aureus). A comparison between developing countries indicated that antibiotic resistance was most widespread in China and India, followed by Brazil and Kenya [115,116].

A recent report from the Infectious Diseases Society of America (IDSA) indicated that there were only ten new drugs in the pipeline (in phase 2 or phase 3 trials) for the treatment of infections caused by pathogens. These drugs, which are under development, might fail to receive regulatory approval by the FDA and are furthermore not guaranteed to be effective against certain antibiotic-resistant pathogens [112].

Potentiating the activity of existing antibiotics using combination therapies could be an alternative strategy to discovering new antibiotics. A range of anti-microbial peptides, molecules, plant extracts and essential oils, all with anti-microbial activity, have demonstrated such combination effects $[117,118]$. Similarly, seaweeds have been tested in combination with antibiotics to extend the lifespan of fading (off-patent) antibiotics which are utilized in animal production. For example, alginates from certain brown seaweeds have been shown to potentiate the anti-microbial activity of specific antibiotics (i.e., macrolides, $\beta$-lactams and tetracyclines) that are efficacious against pathogens such as Pseudomonas, Acinetobacter and Burkholderia spp. [119]. Functional extracts from the brown seaweeds Laminaria japonica and Sargassum horneri and the red seaweeds Gracilaria sp. and Porphyra dentata potentiated the activity of macrolides such as clarithromycin against antibiotic-resistant E. coli. Ethanolic extracts of some seaweeds, in combination with clarithromycin, were observed to synergistically inhibit bacterial growth by inhibiting the activity of efflux pumps [120]. Water extracts of two red seaweeds, e.g., Chondrus crispus and Sarcodiotheca gaudichaudii (SG), in combination with tetracycline and streptomycin, significantly enhanced anti-bacterial activity against Salmonella Enteritidis. A water extract from SG at 400 and $800 \mu \mathrm{g} / \mathrm{mL}$, in combination with sub-lethal concentrations of tetracycline ( 1 and $1.63 \mu \mathrm{g} / \mathrm{mL}$ ), showed complete inhibition of bacterial growth, comparable to full strength tetracycline $(23 \mu \mathrm{g} / \mathrm{mL})$ [121]. The proposed mode of action of the combined effect was the inhibition 
of quorum sensing in SE Salmonella, thereby repressing efflux-related gene expression, resulting in the accumulation of tetracycline within the bacterial cell, ultimately leading to cell death [121]. These findings confirmed the in vitro activities of certain seaweeds and their extracts, which can be employed to increase the lifetime of existing antibiotics. Further research needs to be carried out to test such combinatorial effects in in vivo models such as rats and mice, and then in livestock, to validate these findings. Reduced antibiotic consumption in farm animal production is highly desirable and this may be eventually achieved by feed supplementation of probiotic seaweeds.

\section{Commercialization of Various Seaweeds for Animal Feeds}

The global commercial market for seaweeds provides a broad range of products for direct or indirect human uses. This was valued at USD 11.48 Billion in 2017, with a CAGR of $8.42 \%$ [122]. The growing scope of seaweed-based applications in food, agricultural fertilizers, animal feed additives, pharmaceuticals, cosmetics and personal care is expected to significantly boost market demand. Additionally, rising demands for seaweed-derived hydrocolloids such as agar, alginates and carrageenans also contribute significantly to the total volumes and values of the commercial seaweed market (Agriculture and animal feed applications held the second largest seaweed market share in 2017 [123], and these are anticipated to reach much higher values by 2024, due to the impacts of current R\&D (research and development) targeting enhanced animal health and productivity [123]. Table 3 collates information provided by various producers of poultry products with respect to seaweed-based products.

\section{Challenges and Future Prospects}

(a) The effect of seaweed harvesting on the environment: The global seaweed industry largely relies on harvesting seaweed as a natural resource. Over-harvesting due to increases in seaweed demand could negatively impact the environment and the sustainability of supply. Science-based management plans to maintain a sustainable cultivation and collection/ harvest strategy for seaweed biomass are critical, particularly since some seaweeds have growth rates which exceed those of many terrestrial crop plants, indicating that the selection and domestication of such seaweeds for cultivation would be an ideal direction for future sustainability [124].

(b) Macroalgal cultivation systems: A sound production strategy is vital to improve supplies of selected seaweed biomass due to the predicted growing market demand over the next 5 years [122]. However, reliable, sustainable and economically viable cultivation of seaweeds represents a major challenge due to the high costs and labor associated with establishing large-scale industrial plants. Current large-scale facilities do not have sufficient capacity to produce the huge quantities of seaweed biomass that are necessary to meet global demand by the animal feed industry [125]. One major roadblock is the inadequate numbers of commercial seaweed farms with on-land tank facilities. One solution would be to establish large-scale production facilities in low-income countries [126]. In 2014, Asian countries collectively produced more than 10 million metric tonnes of cultivated seaweeds, whereas European nations produced comparatively limited quantities $(10,000-100,000$ metric tonnes) [127]. Integrated multi-trophic aquaculture (IMTA), which involves the co-cultivation of macroalgae with other livestock such as fish and molluscs, could be a viable commercial alternative. This could also create a balanced ecosystem between seaweed crops and aquatic life [128]. 
Table 3. Summary of major seaweed companies supplying poultry feed and additives.

\begin{tabular}{|c|c|c|c|c|c|}
\hline Business Organization & $\begin{array}{l}\text { Product/Source/ } \\
\text { Description }\end{array}$ & $\begin{array}{l}\text { Stage of Development/ } \\
\text { Operation Level }\end{array}$ & $\begin{array}{l}\text { Product Function/ } \\
\text { Claims }\end{array}$ & Animal Health Sector & Web Address \\
\hline Ekogea, UK & $\begin{array}{l}-\mathrm{BCxF}{ }^{\circledR}, \text { prebiotic poultry water } \\
\text { additive (comprised of Ascophyllum } \\
\text { Nodosum). } \\
-\mathrm{BCxS} \text {, animal housing sanitizer, } 100 \% \\
\text { Ascophyllum Nodosum }\end{array}$ & $\begin{array}{l}\text { Commercialized market, } \\
\text { industrial scale }\end{array}$ & $\begin{array}{l}\text {-Reduces mortality; } \\
\text {-Improves feed conversion, } \\
\text { weight gain and overall bird } \\
\text { health, gut health; } \\
\text {-Reduces ammonia emission and } \\
\text { Campylobacter levels. }\end{array}$ & $\begin{array}{l}\text { Poultry, pigs and } \\
\text { other animals }\end{array}$ & $\begin{array}{c}\text { http: } \\
\text { //www.ekogea.co.uk/ }\end{array}$ \\
\hline $\begin{array}{c}\text { Ocean Harvest } \\
\text { Technology, Ireland }\end{array}$ & $\begin{array}{l}\text {-OceanFeed } \\
\text {-Ocean Poultry contains a complex } \\
\text { blend of seaweeds (red, green and } \\
\text { brown) based feed additive }\end{array}$ & $\begin{array}{l}\text { Commercialized market, } \\
\text { industrial scale }\end{array}$ & $\begin{array}{l}\text {-Improves body weight gain; } \\
\text {-Increases breast meat yield } \\
\text { increased. }\end{array}$ & $\begin{array}{l}\text { Poultry, pigs and } \\
\text { canines (dogs) }\end{array}$ & $\begin{array}{l}\text { https://www. } \\
\text { oceanharvesttechnology. } \\
\text { com }\end{array}$ \\
\hline Olmix Group & $\begin{array}{l}\text { Mycotoxin risk: } \\
\text {-MT.X+ } \\
\text {-MMI.S Digestive efficiency: } \\
\text {-MFeed+ } \\
\text {-DigestSea Immunity: } \\
\text {-Searup } \\
\text {-Algimun }\end{array}$ & $\begin{array}{l}\text { Commercialized market, } \\
\text { industrial scale }\end{array}$ & $\begin{array}{l}\text {-Reduces mycotoxins in feed; } \\
\text {-Immune modulation; } \\
\text {-Improves feed efficiency. }\end{array}$ & $\begin{array}{l}\text { Poultry, pigs } \\
\text { and canines }\end{array}$ & $\begin{array}{c}\text { https: } \\
\text { //www.olmix.com }\end{array}$ \\
\hline $\begin{array}{c}\text { Algea, The Arctic } \\
\text { Company, Kristiansund } \\
\text { - Omagata }\end{array}$ & $\begin{array}{l}\text { AlgaeFeed } 1.4 \\
\text { AlgaeFeed } 3.5 \\
\text { Brown seaweed meal containing } \\
\text { mineral macro and micro elements }\end{array}$ & $\begin{array}{l}\text { Commercialized market, } \\
\text { industrial scale }\end{array}$ & $\begin{array}{l}\text {-Improves animal metabolism } \\
\text { and performance; } \\
\text {-Improves eggshell quality and } \\
\text { production of eggs. }\end{array}$ & $\begin{array}{l}\text { Poultry, pigs, cattle, } \\
\text { fish and equines }\end{array}$ & $\begin{array}{c}\text { https: } \\
\text { //www.algea.com/ }\end{array}$ \\
\hline $\begin{array}{l}\text { FutureFeed, } \\
\text { Australia }\end{array}$ & Asparagopsis seaweed-based diet & $\begin{array}{l}\text { Conducting trials for } \\
\text { commercialization/ } \\
\text { pilot scale }\end{array}$ & $\begin{array}{l}\text {-Anti-bacterial properties; } \\
\text {-Methane reduction in livestock } \\
\text { digestive fermentation. }\end{array}$ & Livestock & $\begin{array}{l}\text { https://www.csiro.au/ } \\
\text { en/Research/AF/ } \\
\text { Areas/Food-security/ } \\
\text { FutureFeed }\end{array}$ \\
\hline $\begin{array}{l}\text { SeaLac, Seaweed } \\
\text { production }\end{array}$ & $\begin{array}{l}\text { Ascophyllum nodosum-based seaweed } \\
\text { supplement- organic dried } \\
\text { seaweed-food grade }\end{array}$ & $\begin{array}{c}\text { Commercialized market, } \\
\text { industrial scale }\end{array}$ & $\begin{array}{l}\text {-Improves feed absorption, } \\
\text { weight gain in broilers; } \\
\text {-Natural alternative to antibiotics; } \\
\text {-Improves egg production, egg } \\
\text { quality and immune response. }\end{array}$ & Poultry, pigs and cattle & http://www.sealac.eu/ \\
\hline
\end{tabular}

There is no implied support for any specific product or manufacturer. Information was gathered from a search of web sites in Sept-Nov, 2019. 
(c) Heavy metals, mineral, plastic and other safety hazards: Marine algae tend to concentrate heavy metals and other mineral contaminants $[129,130]$. Seaweeds for food and feed are always tested to measure levels for trace elements $(\mathrm{As}, \mathrm{Cd}, \mathrm{Pb}, \mathrm{Sn}$ and $\mathrm{Hg}$ ) in order to meet national and international regulation and safety standards [126,131]. Other safety hazards for seaweeds may include anti-nutritional factors, radioactive isotopes, ammonium, dioxins and pesticides. In addition, there are reports that seaweeds increasingly contain traces of plastic particles which might affect the utilization of specific seaweeds for human and animal food [132]. Cultivation of specific seaweed species and or their selected cultivars, targeting specific applications, might be necessary in order to guarantee contaminant-free materials [133].

(d) Seasonal variability, harvesting, processing variability: Seasonal variability affects the nutritional profile of seaweeds [133]. Nutritional and biological activities of seaweeds are primarily due to the presence of compounds such as polysaccharides, carotenoids, fatty acids, proteins, peptides, vitamins, minerals and dietary polyphenols. Seaweeds synthesize several of these compounds in response to complex environmental conditions. Thus, the composition of these varies with seasonal variability. Controlling seasonal variability is a major challenge to maintain consistency in the bioactive compounds as nutrients for feed supplement. Effective measures should be implemented for seaweed harvesting and processing in order to maintain consistency in composition of bioactive material [132].

\section{Conclusions}

This review highlights recent developments in research on selected seaweeds as a valuable and sustainable feed additive for multiple poultry applications. Utilization of selected seaweeds in animal feeds and supplements will improve animal food security and welfare. Advances in scientific evidence from both in vitro and in vivo studies provides promising data to support the utilization of certain seaweeds and their derived compounds to modulate gastrointestinal microbiome and the gut short chain fatty acids (SCFAs).

Dietary polysaccharides from seaweeds are not only a source of anti-microbials but also function as prebiotics and improve the growth of beneficial microflora in gastrointestinal tract. The encouraging data presented in this review supports the need for further research on the use of seaweeds to combat the increasing pressure for an antibiotic-free poultry industry by providing alternatives in the form of natural prebiotics.

Author Contributions: Conceptualization, A.C. and G.K.; Writing-original draft preparation, G.K.; Writing—review and editing, A.C., G.K., B.P., M.T.H.; Supervision, A.C., B.P., M.T.H.; Project administration, A.C. All authors have read and agreed the published version of the manuscript.

Funding: This research received no external funding.

Conflicts of Interest: The authors declare no conflict of interest.

\section{References}

1. Guiry, M.D.; Guiry, G.M.; AlgaeBase. World-Wide Electronic Publication, National University of Ireland, Galway. Available online: https://www.algaebase.org (accessed on 6 July 2020).

2. Piconi, P. Edible Seaweed Market Analysis. Available online: http://www.islandinstitute.org/edible-seaweedmarket-analysis-2020 (accessed on 25 January 2020).

3. Lorbeer, A.J.; Tham, R.; Zhang, W. Potential products from the highly diverse and endemic macroalgae of Southern Australia and pathways for their sustainable production. J. Appl. Phycol. 2013, 25, 717-732. [CrossRef]

4. Gupta, S.; Abu-Ghannam, N. Recent developments in the application of seaweeds or seaweed extracts as a means for enhancing the safety and quality attributes of foods. Innov. Food Sci. Emerg. Technol. 2011, 12, 600-609. [CrossRef]

5. Holdt, S.L.; Kraan, S. Bioactive compounds in seaweed: Functional food applications and legislation. J. Appl. Phycol. 2011, 23, 543-597. [CrossRef] 
6. FAO. The State of World Fisheries and Aquaculture 2018-Meeting the Sustainable Development Goals; FAO: Rome, Italy, 2018.

7. Comtex. Animal Feed Supplements Market Demand Status with Industry Growth 2020 Latest Trends, Top Manufacturers, Analysis by Market Size and Global Share and Forecast to 2026. Available online: https://www.marketwatch.com/press-release/animal-feed-supplements-market-demand-status-withindustry-growth-2020-latest-trends-top-manufacturers-analysis-by-market-size-and-global-share-andforecast-to-2026-2020-05-15 (accessed on 25 May 2020).

8. Allied Market Research. Animal Feed Additives Market by Additive Type (Amino Acids, Antioxidants, Feed Enzymes, Feed Acidifiers, Vitamins, Minerals, Binders, Antibiotics, and Others), Livestock (Swine, Ruminants, Poultry, Aquatic Animals, and Others), Form (Dry, Liquid, and Others), and Function (Single Function and Multifunction): Global Opportunity Analysis and Industry Forecast, 2018-2025. Available online: https://www.alliedmarketresearch.com/animal-feed-additives-market (accessed on 10 September 2019).

9. Evans, F.D.; Critchley, A.T. Seaweeds for animal production use. J. Appl. Phycol. 2014, 26, 891-899. [CrossRef]

10. Mišurcová, L. Chemical composition of seaweeds. In Handbook of Marine Macroalgae: Biotechnology and Applied Phycology; John Wiley \& Sons: West Sussex, UK, 2011; pp. 173-192.

11. Peng, Y.; Hu, J.; Yang, B.; Lin, X.P.; Zhou, X.F.; Yang, X.W.; Liu, Y. Chemical composition of seaweeds. In Seaweed Sustainability: Food and Non-Food Applications; Academic Press: Cambridge, MA, USA, 2015; pp. 79-124.

12. Øverland, M.; Mydland, L.T.; Skrede, A. Marine macroalgae as sources of protein and bioactive compounds in feed for monogastric animals. J. Sci. Food Agric. 2019, 99, 13-24. [CrossRef] [PubMed]

13. Amerah, A.M.; Ravindran, V.; Lentle, R.G.; Thomas, D.G. Feed particle size: Implications on the digestion and performance of poultry. Worlds Poult. Sci. J. 2007, 63, 439-455. [CrossRef]

14. El-Deek, A.A.; Brikaa, M.A. Nutritional and biological evaluation of marine seaweed as a feedstuff and as a pellet binder in poultry diet. Int. J. Poult. Sci. 2009, 8, 875-881. [CrossRef]

15. Abudabos, A.M.; Okab, A.B.; Aljumaah, R.S.; Samara, E.M.; Abdoun, K.A.; Al-Haidary, A.A. Nutritional value of green seaweed (Ulva lactuca) for broiler chickens. Ital. J. Anim. Sci. 2013, 12, e28. [CrossRef]

16. Marković, R.; Šefer, D.; Krstić, M.; Petrujkić, B. Effect of different growth promoters on broiler performance and gut morphology. Arch. Med. Vet. 2009, 41, 163-169. [CrossRef]

17. Cañedo-Castro, B.; Piñón-Gimate, A.; Carrillo, S.; Ramos, D.; Casas-Valdez, M. Prebiotic effect of Ulva rigida meal on the intestinal integrity and serum cholesterol and triglyceride content in broilers. J. Appl. Phycol. 2019, 1-9. [CrossRef]

18. Choi, Y.J.; Lee, S.R.; Oh, J.W. Effects of dietary fermented seaweed and seaweed fusiforme on growth performance, carcass parameters and immunoglobulin concentration in broiler chicks. Asian-Australas J. Anim. Sci. 2014, 27, 862-870. [CrossRef] [PubMed]

19. Gumus, R.; Urcar Gelen, S.; Koseoglu, S.; Ozkanlar, S.; Ceylan, Z.G.; Imik, H. The effects of fucoxanthin dietary inclusion on the growth performance, antioxidant metabolism and meat quality of broilers. Rev. Bras. Cienc. Avic. 2018, 20, 487-496. [CrossRef]

20. Surai, P.F. Selenium in poultry nutrition 1. Antioxidant properties, deficiency and toxicity. Worlds Poult. Sci. J. 2002, 58, 333-347. [CrossRef]

21. Sobotik, E.; Nelson, J.; Archer, G. The effect of feeding a seaweed extract during heat stress on broiler production and stress. In Proceedings of the Poultry Science Association Annual Meeting, San Antonio, TX, USA, 23-26 July 2018.

22. El-Deek, A.A.; Al-Harthi, M.A.; Abdalla, A.A.; Elbanoby, M.M. The use of brown algae meal in finisher broiler diets. Egypt. Poult. Sci. 2011, 3, 767-781.

23. Kumar, A.K. Effect of Sargassum wightii on growth, carcass and serum qualities of broiler chickens. Vet. Sci. Res. 2018, 3, 156.

24. Wiseman, M. Evaluation of Tasco ${ }^{\circledR}$ as A Candidate Prebiotic in Broiler Chickens. Master's Thesis, Dalhousie University, Halifax, NS, Canada, 2012.

25. Walk, C.L.; Addo-Chidie, E.K.; Bedford, M.R.; Adeola, O. Evaluation of a highly soluble calcium source and phytase in the diets of broiler chickens. Poult. Sci. 2012, 91, 2255-2263. [CrossRef] 
26. Bradbury, E.J.; Wilkinson, S.J.; Cronin, G.M.; Walk, C.L.; Cowieson, A.J. The effect of marine calcium source on broiler leg integrity. In Proceedings of the 23rd Annual Australian Poultry Science Symposium, Sydney, Australia, 19-22 February 2012; pp. 85-88.

27. Bradbury, E.J.; Wilkinson, S.J.; Cronin, G.M.; Thomson, P.; Walk, C.L.; Cowieson, A.J. Evaluation of the effect of a highly soluble calcium source in broiler diets supplemented with phytase on performance, nutrient digestibility, foot ash, mobility and leg weakness. Anim. Prod. Sci. 2017, 57, 2016. [CrossRef]

28. Karimi, S.H. Effects of Red Seaweed (Palmaria palmata) Supplemented Diets Fed to Broiler Chickens Raised under Normal or Stressed Conditions. Master's Thesis, Dalhousie University, Halifax, NS, Canada, 2015.

29. Qadri, S.S.N.; Biswas, A.; Mandal, A.B.; Kumawat, M.; Saxena, R.; Nasir, A.M. Production performance, immune response and carcass traits of broiler chickens fed diet incorporated with Kappaphycus alvarezii. J. Appl. Phycol. 2019, 31, 753-760. [CrossRef]

30. Balasubramanian, B.; Koo, J.S.; Deun, S.K.; Park, J.H.; Recharla, N.; Park, S.; Kim, I.H. Influence of marine red seaweed supplementation on growth performance, blood metabolites, breast muscle meat quality, fecal consistency score, excreta microbial shedding and noxious gas emission in broilers. In Proceedings of the Poultry Science Association Annual Meeting, San Antonio, TX, USA, 23-26 July 2019.

31. Bach, S.J.; Wang, Y.; McAllister, T.A. Effect of feeding sun-dried seaweed (Ascophyllum nodosum) on fecal shedding of Escherichia coli O157:H7 by feedlot cattle and on growth performance of lambs. Anim. Feed Sci. Technol. 2008, 142, 17-32. [CrossRef]

32. Michalak, I.; Chojnacka, K.; Dobrzański, Z.; Górecki, H.; Zielińska, A.; Korczyński, M.; Opaliński, S. Effect of macroalgae enriched with microelements on egg quality parameters and mineral content of eggs, eggshell, blood, feathers and droppings. J. Anim. Physiol. Anim. Nutr. 2011, 95, 374-387. [CrossRef]

33. Wang, S.B.; Jia, Y.H.; Wang, L.H.; Zhu, F.H.; Lin, Y.T. Enteromorpha prolifera supplemental level: Effects on laying performance, egg quality, immune function and microflora in feces of laying hens. Chin. J. Anim. Nutr. 2013, 25, 1346-1352.

34. Li, Q.; Luo, J.; Wang, C.; Tai, W.; Wang, H.; Zhang, X.; Liu, K.; Jia, Y.; Lyv, X.; Wang, L.; et al. Ulvan extracted from green seaweeds as new natural additives in diets for laying hens. J. Appl. Phycol. 2018, 30, 2017-2027. [CrossRef]

35. Carrillo, S.; López, E.; Casas, M.M.; Avila, E.; Castillo, R.M.; Carranco, M.E.; Calvo, C.; Pérez-Gil, F. Potential use of seaweeds in the laying hen ration to improve the quality of n-3 fatty acid enriched eggs. J. Appl. Phycol. 2008, 20, 721-728. [CrossRef]

36. Al-Harthi, M.A.; El-Deek, A.A. Effect of different dietary concentrations of brown marine algae (Sargassum dentifebium) prepared by different methods on plasma and yolk lipid profiles, yolk total carotene and lutein plus zeaxanthin of laying hens. Ital. J. Anim. Sci. 2012, 11, e64. [CrossRef]

37. Choi, Y.; Lee, E.C.; Na, Y.; Lee, S.R. Effects of dietary supplementation with fermented and non-fermented brown algae by-products on laying performance, egg quality, and blood profile in laying hens. Asian-Australas. J. Anim. Sci. 2018, 31, 1654-1659. [CrossRef] [PubMed]

38. Stupart, C. Supplementation of Red Seaweed (Chondrus crispus) and Tasco ${ }^{\circledR}$ (Ascophyllum nodosum) in Laying Hen Diets. Master's Thesis, Dalhousie University, Halifax, NS, Canada, 2019.

39. Kulshreshtha, G.; Rathgeber, B.; Stratton, G.; Thomas, N.; Evans, F.; Critchley, A.; Hafting, J.; Prithiviraj, B. Immunology, health, and disease: Feed supplementation with red seaweeds, Chondrus crispus and Sarcodiotheca gaudichaudii, affects performance, egg quality, and gut microbiota of layer hens. Poult. Sci. 2014, 93. [CrossRef] [PubMed]

40. Abbaspour, B.; Davood, S.S.; Mohammadi-Sangcheshmeh, A. Dietary supplementation of Gracilariopsis persica is associated with some quality related sera and egg yolk parameters in laying quails. J. Sci. Food Agric. 2015, 95, 643-648. [CrossRef]

41. Mandal, A.B.; Biswas, A.; Mir, N.A.; Tyagi, P.K.; Kapil, D.; Biswas, A.K. Effects of dietary supplementation of Kappaphycus alvarezii on productive performance and egg quality traits of laying hens. J. Appl. Phycol. 2019, 31, 2065-2072. [CrossRef]

42. Kiarie, E.G.; Mills, A. Role of feed processing on gut health and function in pigs and poultry: Conundrum of optimal particle size and hydrothermal regimens. Front. Vet. Sci. 2019, 6, 19. [CrossRef] [PubMed]

43. Iqbal, Z.; Drake, K.; Swick, R.A.; Perez-Maldonado, R.A.; Ruhnke, I. Feed particle selection and nutrient intake altered by pecking stone consumption and beak length in free-range laying hens. Anim. Nutr. 2019, 5, 140-147. [CrossRef] 
44. Jacob, J.; Pescatore, T. Avian Digestive System. Available online: http://www2.ca.uky.edu/agcomm/pubs/ ASC/ASC203/ASC203.pdf (accessed on 6 November 2019).

45. Missotten, J.A.; Michiels, J.; Dierick, N.; Ovyn, A.; Akbarian, A.; De Smet, S. Effect of fermented moist feed on performance, gut bacteria and gut histo-morphology in broilers. Br. Poult. Sci. 2013, 54, 627-634. [CrossRef] [PubMed]

46. Xie, P.J.; Huang, L.X.; Zhang, C.H.; Zhang, Y.L. Nutrient assessment of olive leaf residues processed by solid-state fermentation as an innovative feedstuff additive. J. Appl. Microbiol. 2016, 121, 28-40. [CrossRef] [PubMed]

47. Lin, H.T.V.; Lu, W.J.; Tsai, G.J.; Chou, C.T.; Hsiao, H.I.; Hwang, P.A. Enhanced anti-inflammatory activity of brown seaweed Laminaria japonica by fermentation using Bacillus subtilis. Process Biochem. 2016, 51, 1945-1953. [CrossRef]

48. Canibe, N.; Jensen, B.B. Fermented liquid feed-Microbial and nutritional aspects and impact on enteric diseases in pigs. Anim. Feed Sci. Technol. 2012, 173, 17-40. [CrossRef]

49. Carrillo, S.; Ríos, V.H.; Calvo, C.; Carranco, M.E.; Casas, M.; Pérez-Gil, F. N-3 Fatty acid content in eggs laid by hens fed with marine algae and sardine oil and stored at different times and temperatures. J. Appl. Phycol. 2012, 24, 593-599. [CrossRef]

50. Rizk, Y.S.; Ismail, I.I.; Hafsa, S.H.A.; Eshera, A.A.; Tawfeek, F.A. Effect of dietary green tea and dried seaweed on productive and physiological performance of laying hens during late phase of production. Egypt. Poult. Sci. J. 2017, 37, 685-706. [CrossRef]

51. Bai, J.; Wang, R.; Yan, L.; Feng, J. Co-supplementation of dietary seaweed powder and antibacterial peptides improves broiler growth performance and immune function. Braz. J. Poult. Sci. 2019, 21. [CrossRef]

52. Brennan, K.M.; Araujo, L.; Encina, C.; Salvá, B.; Flores, R. Effect of an algae-based antioxidant supplement containing selenium yeast on chicken meat quality. In Proceedings of the Poultry Science Association Annual Meeting, San Antonio, TX, USA, 23-26 July 2013.

53. Bortoluzzi, C.; Schmidt, J.M.; Bordignon, H.L.F.; Fülber, L.M.; Layter, J.R.; Fernandes, J.I.M. Efficacy of yeast derived glucomannan or algae-based antioxidant or both as feed additives to ameliorate mycotoxicosis in heat stressed and unstressed broiler chickens. Livest. Sci. 2016, 193, 20-25. [CrossRef]

54. Habold, C.; Reichardt, F.; Le Maho, Y.; Angel, F.; Liewig, N.; Lignot, J.H.; Oudart, H. Clay ingestion enhances intestinal triacylglycerol hydrolysis and non-esterified fatty acid absorption. Br. J. Nutr. 2009, 102, $249-257$. [CrossRef]

55. Frobose, H.L.; Erceg, J.A.; Fowler, S.Q.; Tokach, M.D.; DeRouchey, J.M.; Woodworth, J.C.; Dritz, S.S.; Goodband, R.D. The progression of deoxynivalenol-induced growth suppression in nursery pigs and the potential of an algae-modified montmorillonite clay to mitigate these effects. J. Anim. Sci. 2016, 94, 3746-3759. [CrossRef]

56. Suarez, M.G.; Gallissot, M.; Cierpinski, P. Effect of an algae-clay mix on the use by broiler chickens of a diet containing corn DDGS. In Proceedings of the 4th International Poultry Meat Congress, Antalya, Turkey, 26-30 April 2017; pp. 321-325.

57. Fumonisins, J.; Laurain, M.; Gallissot, M.; Tavares, M.N. Combating the most occurring mycotoxin in South America. In Proceedings of the Poultry Science Association Latin American Annual Meeting, Sao Paulo, Brazil, 6-8 November 2018.

58. Rychen, G.; Aquilina, G.; Azimonti, G.; Bampidis, V.; de Lourdes Bastos, M.; Bories, G.; Chesson, A.; Cocconcelli, P.S.; Flachowsky, G.; Gropp, J.; et al. Safety and efficacy of a preparation of algae interspaced bentonite as a feed additive for all animal species. EFSA J. 2016, 14. [CrossRef]

59. Ventura, M.R.; Castañon, J.I.R.; McNab, J.M. Nutritional value of seaweed (Ulva rigida) for poultry. Anim. Feed Sci. Technol. 1994, 49, 87-92. [CrossRef]

60. Cherry, P.; Yadav, S.; Strain, C.R.; Allsopp, P.J.; Mcsorley, E.M.; Ross, R.P.; Stanton, C. Prebiotics from seaweeds: An ocean of opportunity? Mar. Drugs. 2019, 17, 327. [CrossRef] [PubMed]

61. Gudiel-Urbano, M.; Goñi, I. Effect of edible seaweeds (Undaria pinnatifida and Porphyra ternera) on the metabolic activities of intestinal microflora in rats. Nutr. Res. 2002, 22, 323-331. [CrossRef]

62. Khosravi, M.; Gharibi, D.; Kaviani, F.; Mohammadidust, M. The antibacterial and immunomodulatory effects of carbohydrate fractions of the seaweed gracilaria persica. J. Med. Microbiol. Infect. Dis. 2018, 6, 57-61. [CrossRef] 
63. Ford, L.; Stratakos, A.C.; Theodoridou, K.; Dick, J.T.; Sheldrake, G.N.; Linton, M.; Corcionivoschi, N.; Walsh, P.J. Polyphenols from brown seaweeds as a potential antimicrobial agent in animal feeds. ACS Omega 2020, 5, 9093-9103. [CrossRef]

64. Alghazeer, R.; Whida, F.; Abduelrhman, E.; Gammoudi, F.; Azwai, S. Screening of antibacterial activity in marine green, red and brown macroalgae from the western coast of Libya. Nat. Sci. 2013, 5, 7-14. [CrossRef]

65. Wang, W.; Zhang, P.; Yu, G.L.; Li, C.X.; Hao, C.; Qi, X.; Zhang, L.J.; Guan, H.S. Preparation and anti-influenza A virus activity of $\mathrm{K}$-carrageenan oligosaccharide and its sulphated derivatives. Food Chem. 2012, 133, 880-888. [CrossRef]

66. Carlucci, M.J.; Scolaro, L.A.; Noseda, M.D.; Cerezo, A.S.; Damonte, E.B. Protective effect of a natural carrageenan on genital herpes simplex virus infection in mice. Antivir. Res. 2004, 64, 137-141. [CrossRef]

67. Talarico, L.B.; Damonte, E.B. Interference in dengue virus adsorption and uncoating by carrageenans. Virology 2007, 363, 473-485. [CrossRef] [PubMed]

68. Damonte, E.; Matulewicz, M.; Cerezo, A. Sulfated seaweed polysaccharides as antiviral agents. Curr. Med. Chem. 2012, 11, 2399-2419. [CrossRef] [PubMed]

69. Hardouin, K.; Bedoux, G.; Burlot, A.S.; Donnay-Moreno, C.; Bergé, J.P.; Nyvall-Collén, P.; Bourgougnon, N. Enzyme-assisted extraction (EAE) for the production of antiviral and antioxidant extracts from the green seaweed Ulva armoricana (Ulvales, Ulvophyceae). Algal Res. 2016, 16, 233-239. [CrossRef]

70. Trejo-Avila, L.M.; Morales-Martínez, M.E.; Ricque-Marie, D.; Cruz-Suarez, L.E.; Zapata-Benavides, P.; Morán-Santibañez, K.; Rodríguez-Padilla, C. In vitro anti-canine distemper virus activity of fucoidan extracted from the brown alga Cladosiphon okamuranus. VirusDisease 2014, 25, 474-480. [CrossRef]

71. Elizondo-Gonzalez, R.; Cruz-Suarez, L.E.; Ricque-Marie, D.; Mendoza-Gamboa, E.; Rodriguez-Padilla, C.; Trejo-Avila, L.M. In vitro characterization of the antiviral activity of fucoidan from Cladosiphon okamuranus against Newcastle Disease Virus. Virol. J. 2012, 9, 307. [CrossRef] [PubMed]

72. Pereira, L.; Critchley, A.T. The COVID 19 novel coronavirus pandemic 2020: Seaweeds to the rescue? Why does substantial, supporting research about the antiviral properties of seaweed polysaccharides seem to go unrecognized by the pharmaceutical community in these desperate times? J. Appl. Phycol. 2020, 1-3. [CrossRef]

73. Leonel pereire antiviral activity of seaweeds and their extracts. In Therapeutic and Nutritional Uses of Algae; CRC Press: Boca Raton, FL, USA, 2018; pp. 175-211.

74. Park, H.J.; Kurokawa, M.; Shiraki, K.; Nakamura, N.; Choi, J.S.; Hattori, M. Antiviral activity of the marine alga Symphyocladia latiuscula against herpes simplex virus (HSV-1) in Vitro and its therapeutic efficacy against HSV-1 infection in mice. Biol. Pharm. Bull. 2005, 28, 2258-2262. [CrossRef]

75. Diogo, J.V.; Novo, S.G.; González, M.J.; Ciancia, M.; Bratanich, A.C. Antiviral activity of lambda-carrageenan prepared from red seaweed (Gigartina skottsbergii) against BoHV-1 and SuHV-1. Res. Vet. Sci. 2015, 98, 142-144. [CrossRef]

76. Sweeney, T.; Meredith, H.; Ryan, M.T.; Gath, V.; Thornton, K.; O’Doherty, J.V. Effects of Ascophyllum nodosum supplementation on Campylobacter jejuni colonisation, performance and gut health following an experimental challenge in 10 day old chicks. Innov. Food Sci. Emerg. Technol. 2016, 37, 247-252. [CrossRef]

77. Kulshreshtha, G.; Rathgeber, B.; MacIsaac, J.; Boulianne, M.; Brigitte, L.; Stratton, G.; Thomas, N.A.; Critchley, A.T.; Hafting, J.; Prithiviraj, B. Feed supplementation with red seaweeds, Chondrus crispus and Sarcodiotheca gaudichaudii, reduce Salmonella Enteritidis in laying hens. Front. Microbiol. 2017, 8. [CrossRef]

78. Song, L.; Chen, X.; Liu, X.; Zhang, F.; Hu, L.; Yue, Y.; Li, K.; Li, P. Characterization and comparison of the structural features, immune-modulatory and anti-avian influenza virus activities conferred by three algal sulfated polysaccharides. Mar. Drugs. 2016, 14, 4. [CrossRef]

79. Aguilar-Briseño, J.A.; Cruz-Suarez, L.E.; Sassi, J.F.; Ricque-Marie, D.; Zapata-Benavides, P.; Mendoza-Gamboa, E.; Rodríguez-Padilla, C.; Trejo-Avila, L.M. Sulphated polysaccharides from Ulva clathrata and Cladosiphon okamuranus seaweeds both inhibit viral attachment/entry and cell-cell fusion, in NDV infection. Mar. Drugs. 2015, 13, 697-712. [CrossRef] [PubMed]

80. Paiva, D.M.; Walk, C.L.; McElroy, A.P. Influence of dietary calcium level, calcium source, and phytase on bird performance and mineral digestibility during a natural necrotic enteritis episode. Poult. Sci. 2013, 92, 3125-3133. [CrossRef] [PubMed] 
81. Ravikumar, S.; Ramanathan, G.; Jacob Inbaneson, S.; Ramu, A. Antiplasmodial activity of two marine polyherbal preparations from Chaetomorpha antennina and Aegiceras corniculatum against Plasmodium falciparum. Parasitol. Res. 2011, 108, 107-113. [CrossRef]

82. Sampath-Wiley, P.; Neefus, C.D.; Jahnke, L.S. Seasonal effects of sun exposure and emersion on intertidal seaweed physiology: Fluctuations in antioxidant contents, photosynthetic pigments and photosynthetic efficiency in the red alga Porphyra umbilicalis Kützing (Rhodophyta, Bangiales). J. Exp. Mar. Bio. Ecol. 2008, 361, 83-91. [CrossRef]

83. O'Connor, D.O.; Rubino, J.R. Phenolic compounds. In Disinfection, Sterilization and Preservation; Block, S.S., Ed.; Lea and Febiger: Philadelphia, PA, USA, 1991; pp. 204-224.

84. Potin, P.; Bouarab, K.; Küpper, F.; Kloareg, B. Oligosaccharide recognition signals and defence reactions in marine plant-microbe interactions. Curr. Opin. Microbiol. 1999, 2, 276-283. [CrossRef]

85. Choi, J.; Shin, D.; Kim, M.; Park, J.; Lim, S.; Ryu, S. LsrR-mediated quorum sensing controls invasiveness of salmonella typhimurium by regulating SPI-1 and flagella genes. PLoS ONE 2012, 7, e37059. [CrossRef] [PubMed]

86. Jesudhasan, P.R.; Cepeda, M.L.; Widmer, K.; Dowd, S.E.; Soni, K.A.; Hume, M.E.; Zhu, J.; Pillai, S.D. Transcriptome analysis of genes controlled by luxS/Autoinducer-2 in salmonella enterica serovar typhimurium. Foodborne Pathog. Dis. 2010, 7, 399-410. [CrossRef]

87. Janssens, J.C.A.; Steenackers, H.; Robijns, S.; Gellens, E.; Levin, J.; Zhao, H.; Hermans, K.; De Coster, D.; Verhoeven, T.L.; Marchal, K.; et al. Brominated furanones inhibit biofilm formation by Salmonella enterica serovar Typhimurium. Appl. Environ. Microbiol. 2008, 74, 6639-6648. [CrossRef]

88. Manefield, M.; De Nys, R.; Kumar, N.; Read, R.; Givskov, M.; Steinberg, P.; Kjelleberg, S. Evidence that halogenated furanones from Delisea pulchra inhibit acylated homoserine lactone (AHL)-mediated gene expression by displacing the AHL signal from its receptor protein. Microbiology 1999, 145, 283-291. [CrossRef]

89. Kulshreshtha, G. The Use of Selected Red Macroalgae (Seaweeds) for the Reduction of Salmonella Enteritidis in Poultry. Ph.D. Thesis, Dalhousie University, Halifax, NS, Canada, 2016.

90. Ofek, I.; Mirelman, D.; Sharon, N. Adherence of escherichia coli to human mucosal cells mediated by mannose receptors. Nature 1977, 265, 623-625. [CrossRef]

91. Karbassi, E.; Asadinezhad, A.; Lehocký, M.; Humpolíček, P.; Vesel, A.; Novák, I.; Sáha, P. Antibacterial performance of alginic acid coating on polyethylene film. Int. J. Mol. Sci. 2014, 15, 14684-14696. [CrossRef]

92. Kulshreshtha, G.; Borza, T.; Rathgeber, B.; Stratton, G.S.; Thomas, N.A.; Critchley, A.; Hafting, J.; Prithiviraj, B. Red seaweeds Sarcodiotheca gaudichaudii and chondrus crispus down regulate virulence factors of salmonella enteritidis and induce immune responses in Caenorhabditis elegans. Front. Microbiol. $2016,7$. [CrossRef]

93. Hirayama, M.; Shibata, H.; Imamura, K.; Sakaguchi, T.; Hori, K. High-mannose specific lectin and its recombinants from a carrageenophyta kappaphycus alvarezii represent a potent anti-HIV activity through high-affinity binding to the viral envelope glycoprotein gp120. Mar. Biotechnol. 2016, 18, 215-231. [CrossRef]

94. Zhang, W.; Oda, T.; Yu, Q.; Jin, J.-O. Fucoidan from macrocystis pyrifera has powerful immune-modulatory effects compared to three other fucoidans. Mar. Drugs. 2015, 13, 1084-1104. [CrossRef] [PubMed]

95. Shi, Q.; Wang, A.; Lu, Z.; Qin, C.; Hu, J.; Yin, J. Overview on the antiviral activities and mechanisms of marine polysaccharides from seaweeds. Carbohydr. Res. 2017, 453-454, 1-9. [CrossRef]

96. Patterson, J.A.; Burkholder, K. Application of prebiotics and probiotics in poultry production. Poult. Sci. 2003, 82, 627-631. [CrossRef]

97. Hajati, H.; Rezaei, M. The application of prebiotics in poultry production mitochondrial energetics in response to different fat types in heat-stressed broilers view project effects of fat sources on energetics and redox statues of liver mitochondria in heat-stressd broilers Vi. Artic. Int. J. Poult. Sci. 2010, 9, 298-304. [CrossRef]

98. Gibson, G.R.; Roberfroid, M.B. Dietary modulation of the human colonic microbiota: Introducing the concept of prebiotics. J. Nutr. 1995, 125, 1401-1412. [CrossRef] [PubMed]

99. Ricke, S.C. Impact of prebiotics on poultry production and food safety. Yale J. Biol Med. 2018, 91, 151-159. [PubMed]

100. Cummings, J.H.; Macfarlane, G.T. Gastrointestinal effects of prebiotics. Br. J. Nutr. 2002, 87, S145-S151. [CrossRef] 
101. Reddy, B.S. Possible mechanisms by which pro- and prebiotics influence colon carcinogenesis and tumor growth. J. Nutr. 1999, 129, 1478S-1482S. [CrossRef] [PubMed]

102. Mussatto, S.I.; Mancilha, I.M. Non-digestible oligosaccharides: A review. Carbohydr. Polym. 2007, 68, 587-597. [CrossRef]

103. Apajalahti, J. Comparative gut microflora, metabolic challenges, and potential opportunities. J. Appl. Poult. Res. 2005, 14, 444-453. [CrossRef]

104. Zheng, L.X.; Chen, X.Q.; Cheong, K.L. Current trends in marine algae polysaccharides: The digestive tract, microbial catabolism, and prebiotic potential. Int. J. Biol. Macromol. 2020, 15, 344-354. [CrossRef]

105. Liu, J.; Kandasamy, S.; Zhang, J.; Kirby, C.W.; Karakach, T.; Hafting, J.; Critchley, A.T.; Evans, F.; Prithiviraj, B. Prebiotic effects of diet supplemented with the cultivated red seaweed Chondrus crispus or with fructo-oligo-saccharide on host immunity, colonic microbiota and gut microbial metabolites. BMC Complement. Altern. Med. 2015, 15, 279. [CrossRef]

106. Ramnani, P.; Chitarrari, R.; Tuohy, K.; Grant, J.; Hotchkiss, S.; Philp, K.; Campbell, R.; Gill, C.; Rowland, I. Invitro fermentation and prebiotic potential of novel low molecular weight polysaccharides derived from agar and alginate seaweeds. Anaerobe 2012, 18, 1-6. [CrossRef]

107. Hu, B.; Gong, Q.; Wang, Y.; Ma, Y.; Li, J.; Yu, W. Prebiotic effects of neoagaro-oligosaccharides prepared by enzymatic hydrolysis of agarose. Anaerobe 2006, 12, 260-266. [CrossRef]

108. Ai, C.; Jiang, P.; Liu, Y.; Duan, M.; Sun, X.; Luo, T.; Jiang, G.; Song, S. The specific use of alginate from: Laminaria japonica by Bacteroides species determined its modulation of the Bacteroides community. Food Funct. 2019, 10, 4304-4314. [CrossRef]

109. Nakata, T.; Kyoui, D.; Takahashi, H.; Kimura, B.; Kuda, T. Inhibitory effects of laminaran and alginate on production of putrefactive compounds from soy protein by intestinal microbiota in vitro and in rats. Carbohydr. Polym. 2016, 143, 61-69. [CrossRef]

110. Shang, Q.; Shan, X.; Cai, C.; Hao, J.; Li, G.; Yu, G. Dietary fucoidan modulates the gut microbiota in mice by increasing the abundance of: Lactobacillus and Ruminococcaceae. Food Funct. 2016, 7, 3224-3232. [CrossRef]

111. Charoensiddhi, S.; Conlon, M.A.; Methacanon, P.; Franco, C.M.M.; Su, P.; Zhang, W. Gut health benefits of brown seaweed Ecklonia radiata and its polysaccharides demonstrated in vivo in a rat model. J. Funct. Foods 2017, 37, 676-684. [CrossRef]

112. Casewell, M.; Friis, C.; Marco, E.; Mcmullin, P.; Phillips, I. The European ban on growth-promoting antibiotics and emerging consequences for human and animal health. J. Antimicrob. Chemother. 2003, 52, 159-161. [CrossRef] [PubMed]

113. Pickard, J.M.; Zeng, M.Y.; Caruso, R.; Núñez, G. Gut microbiota: Role in pathogen colonization, immune responses, and inflammatory disease. Immunol. Rev. 2017, 279, 70-89. [CrossRef]

114. U.S. Food and Drug Administration. Antimicrobial Resistance. Available online: https://www.fda.gov/ animal-veterinary/safety-health/antimicrobial-resistance (accessed on 25 May 2020).

115. Maday, J. Princeton Study: Antibiotic Resistance Increasing Globally. Available online: https://www.drovers. com/article/princeton-study-antibiotic-resistance-increasing-globally (accessed on 16 November 2019).

116. Van Boeckel, T.P.; Pires, J.; Silvester, R.; Zhao, C.; Song, J.; Criscuolo, N.G.; Gilbert, M.; Bonhoeffer, S.; Laxminarayan, R. Global trends in antimicrobial resistance in animals in low- And middle-income countries. Science 2019, 365. [CrossRef]

117. Hussin, W.A.; El-Sayed, W.M. Synergic interactions between selected botanical extracts and tetracycline against gram positive and gram negative bacteria. J. Biol. Sci. 2011, 11, 433-441. [CrossRef]

118. Chovanová, R.; Mezovská, J.; Vaverková, Š.; Mikulášová, M. The inhibition the Tet(K) efflux pump of tetracycline resistant Staphylococcus epidermidis by essential oils from three Salvia species. Lett. Appl. Microbiol. 2015, 61, 58-62. [CrossRef]

119. Khan, S.; Tøndervik, A.; Sletta, H.; Klinkenberg, G.; Emanuel, C.; Onsøyen, E.; Myrvold, R.; Howe, R.A.; Walsh, T.R.; Hill, K.E.; et al. Overcoming drug resistance with alginate oligosaccharides able to potentiate the action of selected antibiotics. Antimicrob. Agents Chemother. 2012, 56, 5134-5141. [CrossRef] [PubMed]

120. Lu, W.-J.; Lin, H.-J.; Hsu, P.-H.; Lai, M.; Chiu, J.-Y.; Lin, H.-T.V. Brown and red seaweeds serve as potential efflux pump inhibitors for drug-resistant escherichia coli. Evid.-Based Complement. Altern. Med. 2019. [CrossRef] 
121. Prithiviraj, B.; Kulshreshtha, G. Use of Floridoside or Isethionic Acid to Potentiate Antimicrobial Activity of Antibiotics. Available online: https://patents.google.com/patent/US20190038651A1/en (accessed on 20 January 2020).

122. Fortune Business Insight. Commercial Seaweed Market Size, Share and Global Trend by Product Type (Red, Brown, Green), by Form (Flakes, Powder, Liquid), by END user (Food and Beverage, Agriculture Fertilizer, Animal Feed Additives, Pharmaceuticals, Cosmetics, and Personal Care) and Regional Forecast Till 2025. Available online: http://web.archive.org/web/20200510003328/https://www.fortunebusinessinsights.com/ industry-reports/commercial-seaweed-market-100077 (accessed on 24 September 2019).

123. Grand View Research Inc. Commercial Seaweeds Market Size, Share \& Trends Analysis Report By Product (Brown Seaweeds, Red Seaweeds, Green Seaweeds), By Form (Liquid, Powdered, Flakes), By Application, By Region, And Segment Forecasts, 2020-2027. Available online: https://www.grandviewresearch.com/ industry-analysis/commercial-seaweed-market (accessed on 25 May 2020).

124. Mac Monagail, M.; Cornish, L.; Morrison, L.; Araújo, R.; Critchley, A.T. Sustainable harvesting of wild seaweed resources. Eur. J. Phycol. 2017, 52, 371-390. [CrossRef]

125. Cornish, L. The animal kingdom and seaweeds. J. Mar. Sci. Pers. Comm. 2020. in preparation.

126. Lerat, Y.; Cornish, M.L.; Critchley, A.T. Applications of algal biomass in global food and feed markets: From traditional usage to the potential for functional products. In Blue Biotechnology: Production and Use of Marine Molecules; Wiley YHC Wiley-VCH Verlag GmbH \& Co. KGaA: Weinheim, Germany, 2018; pp. 143-189.

127. Buschmann, A.H.; Camus, C.; Infante, J.; Neori, A.; Israel, Á.; Hernández-González, M.C.; Pereda, S.V.; Gomez-Pinchetti, J.L.; Golberg, A.; Tadmor-Shalev, N.; et al. Seaweed production: Overview of the global state of exploitation, farming and emerging research activity. Eur. J. Phycol. 2017, 52, 391-406. [CrossRef]

128. Ratcliff, J.J.; Wan, A.H.L.; Edwards, M.D.; Soler-Vila, A.; Johnson, M.P.; Abreu, M.H.; Morrison, L. Metal content of kelp (Laminaria digitata) co-cultivated with Atlantic salmon in an Integrated Multi-Trophic Aquaculture system. Aquaculture 2016, 450, 234-243. [CrossRef]

129. Feng, Z.; Zhang, T.; Shi, H.; Gao, K.; Huang, W.; Xu, J.; Wang, J.; Wang, R.; Li, J.; Gao, G. Microplastics in bloom-forming macroalgae: Distribution, characteristics and impacts. J. Hazard. Mater. 2020, 397, 122752. [CrossRef] [PubMed]

130. Feng, Z.; Zhang, T.; Wang, J.; Huang, W.; Wang, R.; Xu, J.; Fu, G.; Gao, G. Spatio-temporal features of microplastics pollution in macroalgae growing in an important mariculture area, China. Sci. Total Environ. 2020, 719, 137490. [CrossRef]

131. Mac Monagail, M.; Morrison, L. Arsenic speciation in a variety of seaweeds and associated food products. Compr. Anal. Chem. 2019, 85, 267-310.

132. Rajauria, G. Seaweeds: A sustainable feed source for livestock and aquaculture. Seaweed Sustain. 2015, 389-420.

133. Stengel, D.B.; Connan, S.; Popper, Z.A. Algal chemodiversity and bioactivity: Sources of natural variability and implications for commercial application. Biotechnol. Adv. 2011, 29, 483-501. [CrossRef]

(C) 2020 by the authors. Licensee MDPI, Basel, Switzerland. This article is an open access article distributed under the terms and conditions of the Creative Commons Attribution (CC BY) license (http://creativecommons.org/licenses/by/4.0/). 